\title{
Physiology, signaling, and pharmacology of opioid receptors and their ligands in the gastrointestinal tract: current concepts and future perspectives
}

\author{
Marta Sobczak • Maciej Sałaga • Martin A. Storr • \\ Jakub Fichna
}

Received: 28 November 2012/ Accepted: 10 January 2013/Published online: 9 February 2013

(C) The Author(s) 2013. This article is published with open access at Springerlink.com

\begin{abstract}
Opioid receptors are widely distributed in the human body and are crucially involved in numerous physiological processes. These include pain signaling in the central and the peripheral nervous system, reproduction, growth, respiration, and immunological response. Opioid receptors additionally play a major role in the gastrointestinal (GI) tract in physiological and pathophysiological conditions. This review discusses the physiology and pharmacology of the opioid system in the GI tract. We additionally focus on GI disorders and malfunctions, where pathophysiology involves the endogenous opioid system, such as opioid-induced bowel dysfunction, opioid-induced constipation or abdominal pain. Based on recent reports in the field of pharmacology and medicinal chemistry, we will also discuss the opportunities of targeting the opioid system, suggesting future treatment options for functional disorders and inflammatory states of the GI tract.
\end{abstract}

Keywords Abdominal pain - Functional gastrointestinal disorders · Inflammatory bowel diseases - Opioid-induced bowel dysfunction - Opioid receptors and their ligands

$\begin{array}{ll}\text { Abbreviations } & \\ \text { 5-HT } & \text { 5-Hydroxytryptamine } \\ \text { AC } & \text { Adenylyl cyclase }\end{array}$

M. Sobczak · M. Sałaga $\cdot$ J. Fichna $(\bowtie)$

Department of Biomolecular Chemistry, Faculty of

Medicine, Medical University of Lodz,

Mazowiecka 6/8, 92-215 Lodz, Poland

e-mail: jakub.fichna@umed.lodz.pl

M. A. Storr

Division of Gastroenterology, Department of Medicine, Ludwig

Maximilians University of Munich, Munich, Germany
AQ rt RT-PCR Absolute quantitative real-time reverse transcriptase polymerase chain reaction

BAM

BBB

Bovine adrenal medulla peptide

CB1R

CD

CFTR

CLP

CNS

DADLE

DALDA

DAMGO

DFU

DOR

DSS

EM

ENS

GI

GRK2/3

IBD

KOR

LMMP

$\mathrm{LPH}$

MMCP-1

mNTS

MNTX

MOR

$\mathrm{MSH}$

OBD

OIC
Blood brain barrier

Cannabinoid receptor type 1

Crohn's disease

Cystic fibrosis transmembrane

conductance regulator

Cecal ligation and perforation

Central nervous system

$\left[\mathrm{D}-\mathrm{Ala}^{2}, \mathrm{D}-\mathrm{Leu}^{5}\right]$-Enkephalin

Tyr-D-Arg-Phe-Lys- $\mathrm{NH}_{2}$ $\left[\mathrm{D}-\mathrm{Ala}^{2}, \mathrm{~N}-\mathrm{MePhe}{ }^{4}\right.$, Gly-ol]-Enkephalin

5,5-Dimethyl-3-(3-fluorophenyl)-

4-(4-methylsulphonyl)-phenyl-2(5H)-

furanone

$\delta$-Opioid receptor

Dextran sulfate sodium

Endomorphin

Enteric nervous system

Gastrointestinal

GPCR kinase 2/3

Inflammatory bowel diseases

$\kappa$-Opioid receptor

Longitudinal muscle-myenteric plexus

Lipotropin

Mouse mast cell protease-1

Medial subnucleus of the tractus

salitarius

Methylnaltrexone

$\mu$-opioid receptor

Melanocyte-stimulating hormone

Opioid-induced bowel dysfunction

Opioid-induced constipation 


$\begin{array}{ll}\text { OPRD1 } & \begin{array}{l}\delta \text {-opioid receptor gene } \\ \text { O-opioid receptor gene } \\ \text { OPRK1 }\end{array} \\ \text { OPRM1 } & \begin{array}{l}\mu \text {-opioid receptor gene } \\ \text { Peripherally acting } \mu \text {-opioid receptor } \\ \text { antagonist }\end{array} \\ \text { PAMORA } & \text { Prodynorphin } \\ \text { PDYN } & \text { Proenkephalin } \\ \text { PENK } & \text { Phosphoinositide 3-kinase } \\ \text { PI3K } & \text { Phospholipase } \beta \\ \text { PLC } \beta & \text { Phorbol 12-mirystate 13-acetate } \\ \text { PMA } & \text { Postoperative ileus } \\ \text { POI } & \text { Proopiomelanocortin } \\ \text { POMC } & \text { Rescue-free bowel movements } \\ \text { RFBM } & \text { Regulator of G-protein signaling 4 } \\ \text { RGS4 } & \text { Salvinorin A } \\ \text { SA } & \text { Single nucleotide polymorphism } \\ \text { SNP } & 2,4,6 \text {-trinitrobenzene sulfonic acid } \\ \text { TNBS } & \text { Ulcerative colitis } \\ \text { UC } & \text { Voltage-gated calcium channel } \\ \text { VGCC } & \end{array}$

\section{Introduction}

Opioids are broadly used medical and recreational psychoactive substances worldwide. For centuries, they have been used for acute and chronic treatment of moderate to severe pain, in particular in cancer patients. Opioids have also been administered in patients after surgical interventions to achieve sufficient post-operative pain control. Major limitations of prolonged opioid use result from severe adverse effects, including slowing of GI motility, respiratory depression, development of tolerance and physical dependence.

The analgesic effect of opioids implies their action in the central nervous system. However, opioids are also active in the periphery and this encouraged their use for therapeutic purposes also in the GI tract, like in the treatment of diarrhea or abdominal pain. Identification of opioid receptors in the GI tract and characterisation of their role in GI pathophysiology made them an attractive pharmacological target for numerous pathophysiological conditions.

In this review, we discuss the physiology and pharmacology of the opioid system, in particular in the GI tract. We additionally focus on GI disorders and malfunction, where pathophysiology is related to the endogenous opioid system, such as opioid-induced bowel dysfunction (OBD), opioid-induced constipation (OIC) or abdominal pain. Based on recent reports in pharmacology and medicinal chemistry, we will also explore the possibilities of targeting the opioid system for the treatment of functional disorders and inflammatory states of the GI tract.

\section{Opioid receptors}

The endogenous opioid system is composed of cell surface receptors [1] and their endogenous ligands [2]. Opioid receptors were divided into three major types: $\mu$ (mu, MOR), $\delta$ (delta, DOR), and $\kappa$ (kappa, KOR) [2-4]. All three opioid receptor types were cloned in the 1990s, first DOR from mice [5], followed by KOR [6, 7] and MOR [8]. Over the years opioid receptors were characterized at biochemical and pharmacological levels. Further division into subtypes according to their localization, ligands and function has been proposed. However, the classification of opioid receptors into subtypes is still controversial due to unclear criteria, which would enable their proper categorization [9].

Opioid receptors as members of the $\mathrm{G}$ protein-coupled receptor (GPCR) family

Opioid receptors belong to the family of $\mathrm{G}$ protein-coupled receptors (GPCR), one of the largest protein families in mammals. Opioid receptors are integral membrane proteins, coupled to heterotrimeric $\mathrm{G}_{\mathrm{i} / \mathrm{o}}$ proteins. The structure of opioid receptors consists of seven hydrophobic transmembrane domains TM I-VII, three intracellular hydrophobic (i1-i3) and three extracellular (e1-e3) loops, a glycosylated amino and a carboxyl terminus (Fig. 1). The intracellular loop i3 is identical in 20-23 amino acids in all opioid receptors [10, 11]. The C-terminal end is composed of 59, 51, 47 amino acids for MOR, DOR and KOR, respectively, with highly conserved sequence (identical 10-12 amino acids for all opioid receptors) [12].

It has been demonstrated that the transmembrane domains TM V-VII are required for ligand binding in DOR [13]. The other transmembrane domain TM IV and the extracellular loop e2 are responsible for ligand binding in $\mathrm{KOR}$, whereas the extracellular loop e1 is a ligand binding site in MOR [14]. Two of the intracellular loops (i1 and i3),

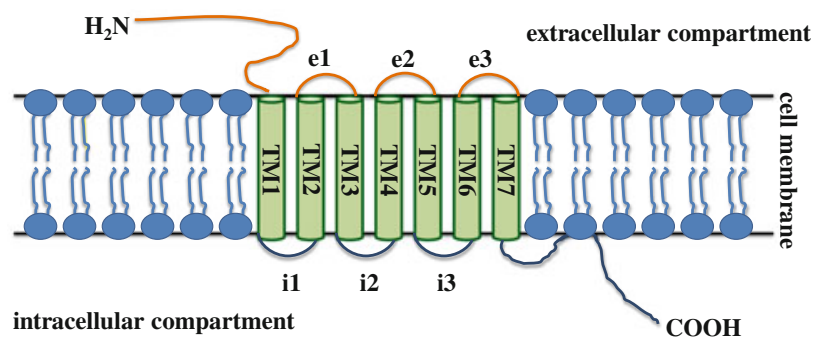

Fig. 1 General structure of $G$ protein-coupled receptors. Opioid receptors are integral membrane proteins, coupled to heterotrimeric $\mathrm{G}$ proteins. The structure of opioid receptors consists of seven hydrophobic transmembrane domains TM I-VII, three intracellular hydrophobic (i1-i3) and three extracellular (e1-e3) loops, a glycosylated amino and a carboxyl terminus 
the C-terminus receptor fragment and a transmembrane domain TM V are engaged in signal transduction pathways and participate in mediating opioid receptor- $\mathrm{G}$ protein interactions [15].

Activation of opioid receptors and signal transduction follow a pattern typical for all GPCRs, which is shown in Fig. 2. Following ligand binding to the opioid active site, receptor conformation changes, which activates intracellular $\mathrm{G}$ proteins. Each $\mathrm{G}$ protein consists of three subunits: $\alpha, \beta$ and $\gamma$. Opioid receptors are coupled with Gai (existing in three forms), $\mathrm{G} \alpha$ o (existing in A and B forms) and $\mathrm{G} \alpha \mathrm{z}$ [16]. $\beta$ and $\gamma$ subunits form a heterodimer, which consists of one of five different $\beta$ and twelve different $\gamma$ proteins [17]. The role of the G $\beta \gamma$ heterodimer is crucial for the function of $\mathrm{G} \alpha$, as it enables proper conformation of $\mathrm{G} \alpha$ while ligand binding to the receptor [18].

The canonical opioid receptor-related signaling pathway involves the dissociation of the heterotrimeric $G$ protein into $G \alpha$ and $G \beta \gamma$ subunits, which is followed by the $G \alpha$ translocation and further interaction with Kir3 (G proteingated inwardly rectifying $\mathrm{K}^{+}$channel). The release of $\mathrm{G} \alpha$ subunit also inhibits adenylyl cyclase (AC) activity. The release of $\mathrm{G} \beta \gamma$ subunit inhibits voltage-gated $\mathrm{Ca}^{2+}$ channels (VGCC, L-type and N-type) and causes activation of $\mathrm{K}^{+}$channels. By inhibition of N-type VGCCs opioid receptor agonists inhibit calcium influx into the cell. Other effectors linked to G $\beta \gamma$ include GPCR kinase 2/3 (GRK), phospholipase C $\beta$ (PLC $\beta$ ), phospatidyloinositol-3-kinase (PI3K), adenylyl cyclase and others [3, 19]. When the $\mathrm{G} \alpha$ subunit activates the intracellular effectors, GTP hydrolyzes to GDP and G $\alpha$ loses its activity and binds to subunit $\mathrm{G} \beta \gamma$ - the recovered complex is inactive and can be further activated.

Many intracellular proteins, like $\beta$-arrestin, calmodulin, calnexin, filamin A, periplakin, RGS4, ribophorin I or ubiquitin interact with opioid receptors and may thus regulate opioid receptor function at a molecular level, like receptor trafficking, desensitization or endocytosis (for review see: Georgoussi et al. [20]). For example, $\beta$-arrestin is a key protein in GPCR desensitization because of blockage of protein-protein interactions, i.e. receptor promotion in clathrin-dependent manner [21]. The lack of $\beta$-arrestin prevents receptor desensitization and the development of opioid tolerance after chronic opioid treatment in vivo $[22,23]$.

\section{Opioid receptor gene expression}

MOR, DOR and KOR are encoded by OPRM1, OPRDI and $O P R K 1$ genes, respectively [24]. The opioid receptor genes are highly conserved in the sequence coding the 7-transmembrane fragment, but vary at the carboxyl and amino termini. This results in differences in the affinity to opioid ligands and distinct signaling pathways [25]. The amino acid sequences in opioid receptors are identical in roughly $60 \%$, which indicates their common origin [26].

The N-terminus of all opioid receptors and the transmembrane domain TMI are encoded by exon 1 , while exon 2

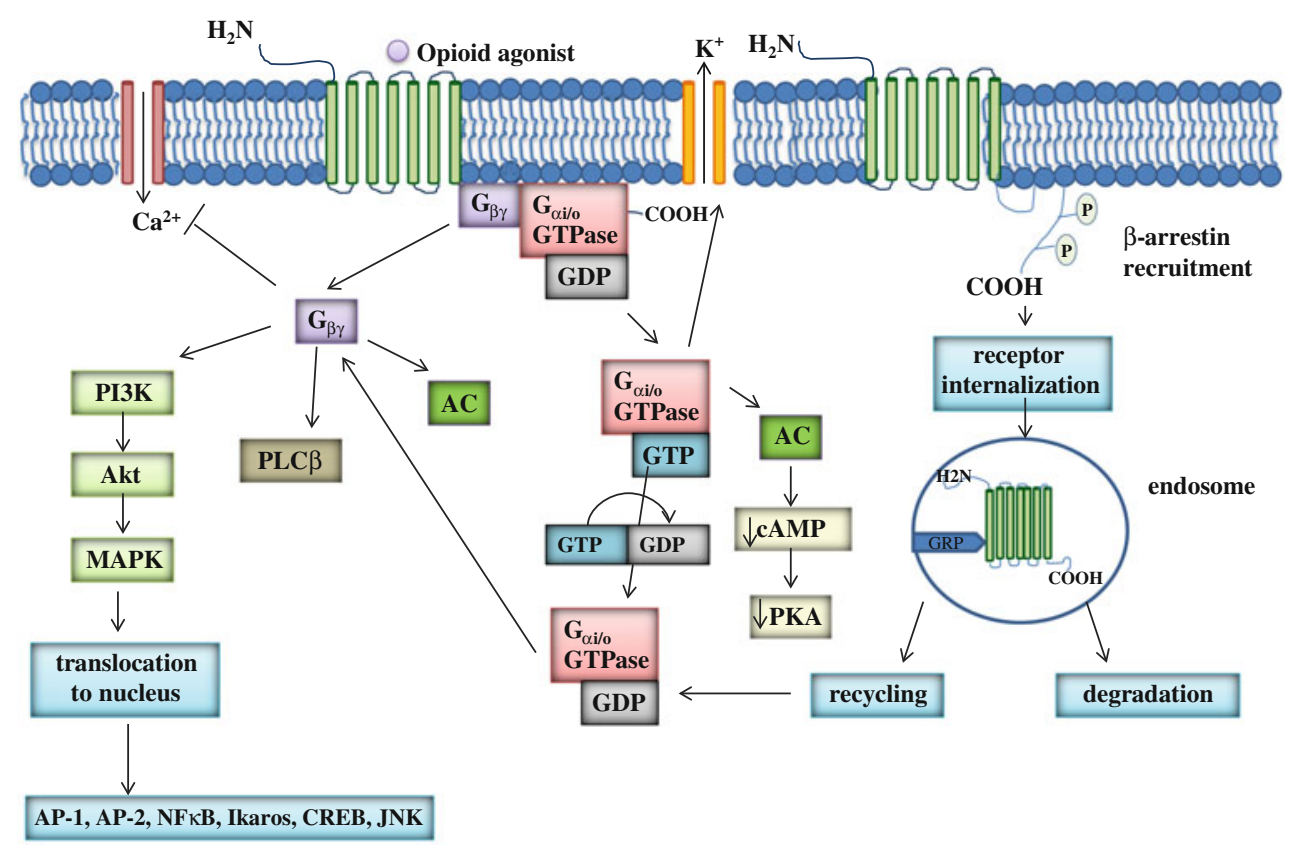

Fig. 2 Opioid receptor-related intracellular signal transduction pathways. Opioid receptors are coupled with $\mathrm{G} \alpha i, \mathrm{G} \alpha \mathrm{o}$ and $\mathrm{G} \alpha \mathrm{z}$ proteins. Secondary transmitters include adenylyl cyclase (AC), GPCR kinase
2/3 (GRK), phospholipase C $\beta$ (PLC $\beta$ ), and phospatidyloinositol-3kinase (PI3K). The release of G $\beta \gamma$ subunit also inhibits voltage-gated $\mathrm{Ca}^{2+}$ channels (VGCC, L-type and N-type) and activates $\mathrm{K}^{+}$channels 
is responsible for coding transmembrane domains TMII-IV. Distal TM domains (TMV-VII) and the intracellular C-terminus are encoded by exon 3 [27]. All genes encoding opioid receptors produce multiple mRNA isoforms, what results from alternative splicing, alternative promoters, but also various sites of polyadenylation and inclusions of noncoding sequences [28].

MOR, the major site of action of opioid drugs, is encoded by the OPRMI gene located in chromosome 6 (6q25.2.) [29]. The OPRM1 gene possesses 23 transcription variants and the most common variant (MOR-1O) consists of 4 exons and encodes 418 amino acids [30]. The differences between $O P R M 1$ gene variants are highly correlated with changes in dosage requirements for some exogenous opioids. These alterations result from occurring polymorphisms and include alternative splicing at both ends $\left(3^{\prime}\right.$ and $5^{\prime}$ ) of mRNA, combined with heterodimerization of the receptors. More than 100 single nucleotide polymorphisms (SNPs) were identified in OPRM1 gene, but their meaning remains in most cases unclear [25].

Several human genetic polymorphisms and their possible implications in opioid treatment, as well as the relationship between these polymorphisms and the clinical outcome have recently been discussed in an excellent review by Finco et al. [31]. The most common SNP in the OPRM1 gene is the substitution A/G (rs 1799971) on exon 1, which causes a change in the MOR protein amino acid sequence (Asn $\rightarrow$ Asp, N40D). This SNP enhances the binding affinity of $\beta$-endorphin at MOR, which causes an increased potency at the receptor [32]. However, the role of SNP A118G in antinociceptive action of MOR ligands is unclear [15, 33-35].

DOR is composed of 372 amino acids. The OPRDI gene, which encodes DOR, is located on $1 \mathrm{p} 36$ and contains 3 exons [36]. Nine DOR-related SNPs, which are common in several ethnicities, have been reported [37]. Single nucleotide polymorphism A/G (rs569356) was shown to increase the activity of $O P R D 1$ promoter, probably by enhanced binding of the transcription factor [38]. The elevated expression of OPRD1 may result in increased rewarding effect of drugs of abuse. Studies on DOR-related SNPs and their possible role in alcohol dependence and drug addiction were recently reported [39].

KOR is encoded by OPRKl gene, which is located on 8q11.2. The major transcription variant possesses four exons ( $5^{\prime}$ is non-coding) and encodes a protein with 380 amino acids [40]. Several SNPs were classified as SNPs related to alcohol dependence. The insertion/deletion (indel) with a net addition of 830 base pairs $1986 \mathrm{bp}$ upstream of the translational start site in OPRK1 reduces promoter activity by about half and is associated with alcohol dependence [41].
Opioid receptors in the central nervous system

A precise quantification of opioid receptor mRNA expression using absolute quantitative real-time reverse transcriptase PCR (AQ rt RT-PCR), together with numerous immunohistochemistry studies revealed a wide distribution of opioid receptors in the central nervous system (CNS) [42]. The highest expression of MOR was observed in cerebellum, caudate nucleus and nucleus accumbens. DOR were identified in hippocampus, cerebral cortex, putamen, caudate nucleus, nucleus accumbens and temporal lobe. The highest expression of KOR was detected in caudate nucleus, nucleus accumbens, hypothalamic nuclei and putamen.

In the CNS opioid receptors are expressed in painmodulating descending pathways, involving locus coeruleus, medulla, and periaqueductal gray area and are mainly involved in pain signaling and antinociception. Opioid receptors also occur in midbrain, limbic and cortical structures and may thus modulate a wide range of other functions, including memory and stress response.

Activation of opioid receptors attenuates neuronal activity by pre- and postsynaptic mechanisms, which include the release of inhibitory neurotransmitters and changes in neuronal excitability [43]. Opioid receptors and their ligands are involved in an intense cross-talk with other endogenous systems. Activation of MOR, which is most crucial in pain relief, activates central dopamine reward pathways and may be involved in euphoria. Other adverse side-effects of MOR activation in the CNS, in particular upon prolonged administration of MOR agonists, include addiction, depression, anxiety, and sedation. These were characterized in many previous reports.

Distribution of opioid receptors in the gastrointestinal tract

In the periphery, opioid receptors are widely distributed in neuronal and non-neuronal tissues, including neuroendocrine, immune and ectodermal cells [10]. In the GI tract they are present in smooth muscle cells and at the terminals of sympathetic and sensory peripheral neurons. It has been shown that opioid receptors are synthesized in the dorsal root ganglion and transported centrally and peripherally to the nerve terminals [44].

The distribution of MOR in the enteric nervous system (ENS) was summarized by Sternini et al. [45]. As shown using autoradiography and radiolabeled agonists and antagonists $\left(\left[{ }^{3} \mathrm{H}\right]\right.$ dihydromorphine, $\left[{ }^{3} \mathrm{H}\right]$ naloxone, and $\left[{ }^{3} \mathrm{H}\right]$ loperamide), MOR are expressed in the submucosal plexus and the myenteric plexus and longitudinal muscle of ileum from various species (including rat, guinea pig, pig, 
human). Some differences in distribution of MOR among studied species were also reported (for review see: [46]).

The expression of DOR in murine enteric neurons was assessed using enhanced green fluorescent protein (GFP), inserted into OPRDl gene [47]. The product of insertion, a 80-kDa protein DOReGFP, was detected in esophagus, gastric corpus and antrum, and small and large intestine. Further studies revealed that DOReGFP is expressed in neuropeptide Y (NPY)-positive secretomotor and vasodilator neurons in the submucosal plexus of the small bowel. Moreover, DOReGFP is also present in excitatory motoneurons and interneurons of the myenteric plexus, which express SP and choline acetyltransferase, and in inhibitory interneurons and motoneurons expressing nitric oxide synthase. DOR is also found in nitrergic myenteric neurons in the mouse colon.

KORs are highly expressed in the periphery, among others in epidermal keratinocytes and dermal fibroblasts, as well as in nerve terminals of joints, muscles and viscera. The expression of KOR was also detected in dorsal and trigeminal root ganglia [48]. In the GI tract, KORs were localized to myenteric and submucosal neurons, fibres in muscle layer, blood vessels and mucosa in rats [49]. Furthermore, AQ rt RT-PCR revealed the presence of KOR in the liver [47].

Importantly, the opioid receptors were also found in high amounts on lymphocytes and macrophages [42].

Physiological role of opioid receptors

in the gastrointestinal tract

Many structural and functional components are responsible for the proper function of the GI tract, including ENS, GI smooth muscle cells, the intestinal mucosa and blood vessels. The ENS consists of two plexus - the myenteric and the submucosal plexus. The localization of the myenteric plexus between longitudinal and circular muscles predestines its involvement in the GI motor activity and its stimulation increases peristalsis. The submucosal plexus controls local secretion and absorption activity [50]. Opioid receptors, which are expressed in the myenteric and the submucosal plexus play a major role in the regulation of the GI transit and mucosal transport of fluids and electrolytes and maintaining GI homeostasis.

Opioids affect primarily neuronal excitability in the enteric circuitry via interaction with major transmitters in the ENS, such as acetylcholine (ACh), SP, neurokinin A (NKA), ATP, vasoactive intestinal peptide (VIP), NPY or 5-hydroxytryptamine (5-HT) [51]. Results from three different studies furthermore suggested an interaction between opioid and glutamate receptors in the guinea pig ileum [52-54]. A recent study by Iwata et al. [55] suggested that the nitrergic pathway may also be involved in the opioid-induced actions in the GI tract. It was shown that the contraction of the mouse ileum induced by morphine administration was inhibited by tetrodotoxin and $\mathrm{N}^{\mathrm{G}}$-nitro-L-arginine, indicating that the potential mechanism of morphine action may be associated with the inhibition of nitric oxide (NO) release from inhibitory nerves.

The major effects of opioid receptor agonists in the GI tract are reduction of tonic/segmental contractions and impairment of peristalsis by inhibition of the release of ACh and SP, as well as decrease of GI secretion by inhibition of the activity of ACh and VIP containing neurons [56] (Fig. 3). The intestinal mucosa has the ability to absorb dietary nutrients, water and electrolytes. The active absorption of $\mathrm{Na}^{+}$and secretion of $\mathrm{Cl}^{-}$across the intestinal mucosa is critical for maintenance of the water-electrolyte balance, defense against bacterial infections and digestive processes [57]. Opioids reduce epithelial secretion and promote water and electrolyte absorption mainly by activation of DOR and MOR [58]. Opioid receptor-mediated increase of cyclic nucleotide concentration stimulates $\mathrm{Cl}^{-}$ secretion and inhibits $\mathrm{Na}^{+} / \mathrm{Cl}^{-}$absorption [59].

In consequence, opioids induce stationary motor patterns: inhibit relaxation of the lower esophageal sphincter, decrease propulsion of smooth muscles in the small and large intestine, increase pyloric and anal sphincter tonus, delay gastric emptying and oral-cecal transit time, and enhance absorption of fluids from intestinal contents. Because of these involvements, the effects of opioid treatment result in nausea, vomiting, altered fluid dynamics and increased GI transit time, constipation, abdominal discomfort or pain (as summarized in Fig. 4).

Interestingly, opioid receptor agonists can modulate the GI function through centrally mediated actions at the sites which are not protected by blood brain barrier (BBB). For example, it was demonstrated that the activation of MOR located in the medial subnucleus of the tractus salitarius (mNTS) affects the GI motor function. The microinjection of MOR agonists (at doses 1-10 fmol) into mNTS decreased the intragastric pressure and phasic contractions, and inhibited gastric motility [60]. The actions of MOR agonists were associated with the suppression of local GABA activity, which is known to decrease gastric tone and motility [61]. In another study, low doses of MOR agonists (30-300 fmol) microinjected into mNTS area) affected gastric motility by decreasing intragastric pressure and phonic contractions. The inhibitory effect of MOR agonists in mNTS was absent following vagotomy or pretreatment with a selective MOR antagonist. This suggests the involvement of opioid receptors and their ligands in vagovagal reflexes through the release of endogenous opioids in the mNTS area. 
Fig. 3 Interaction of opioids with neurotransmitters in the enteric nervous system. Opioids reduce tonic/segmental contractions and impair peristalsis by inhibition of the release of ACh and SP. The decrease of GI secretion is caused by the inhibition of the activity of ACh and VIP containing neurons
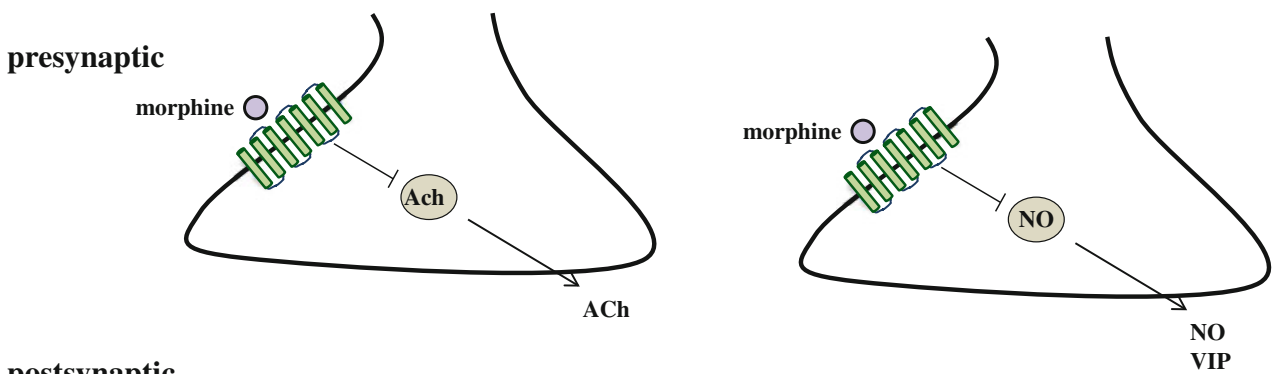

postsynaptic

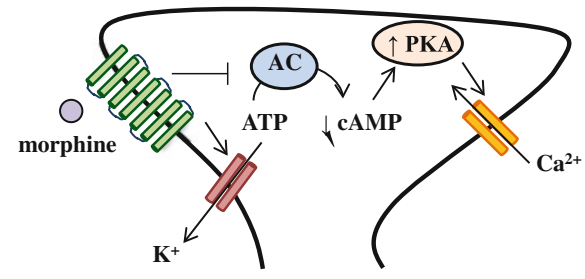

neuronal cell

bodies

interneurone

secretomotor

neurone

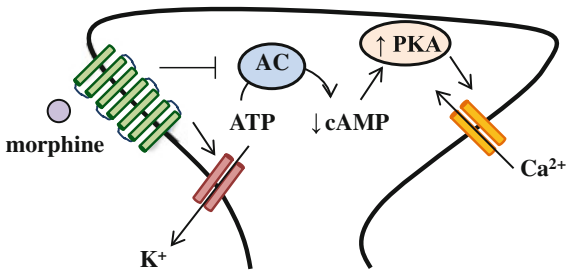

musculomotor neurone

\section{PHARMACOLOGICAL EFFECT}

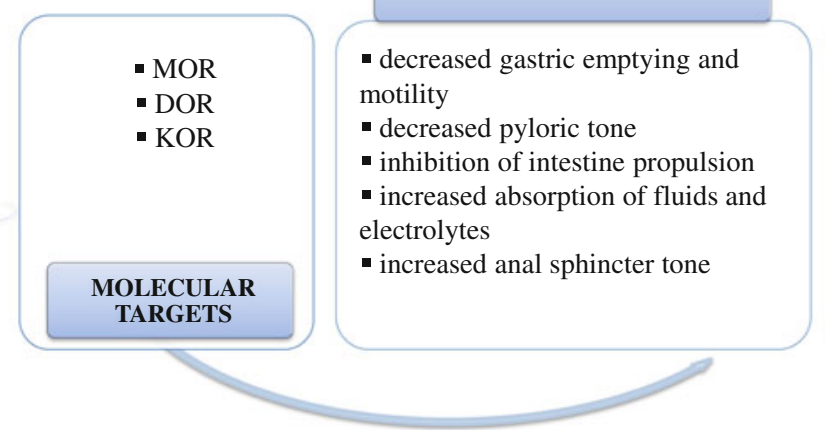

- decreased appetite, increased gastrooesophageal reflux

- vomiting, nausea

- hard, dry stools

- lower absorption of drugs, constipation, abdominal distension

- incomplete evacuation

\section{CLINICAL EFFECT}

Fig. 4 Pharmacological and clinical effects of opioids

\section{Oligomerization of opioid receptors}

Similarly to other GPCR proteins, the opioid receptors can heteromerize under physiological and pathophysiological conditions in order to form functional dimers, heterodimers and oligomers [62-64]. Opioid receptors can interact with each other and can also form complexes with other proteins. For example, DOR can exist as homodimers and in presence of an agonist the dissociation of DOR complex occurs. KOR and DOR can also heterodimerize, but their activity is decreased, when they form a complex [11]. The role of heterodimerization of opioid receptors remains unclear, because highly selective ligands for these heterodimers are not available [65]. However, it was suggested that heterooligomerization might induce changes in receptorrelated signaling and alter ligand binding [66, 67].
It was suggested that the presence of MOR and cannabinoid type 1 receptor (CB1R) heterodimers may result in altered antinociceptive action of opioids. For example, the administration of $\Delta$ 9-tetrahydrocannabinol (THC), a CB1 agonist enhanced the antinociceptive action of morphine due to the formation of a MOR-CB1 complex [68, 69].

\section{Opioid receptor ligands}

\section{Endogenous opioids}

Endogenous opioid peptides are low-molecular compounds, which are produced in the CNS and peripheral 
tissues, like adrenal glands. Endogenous opioid peptides derive from three precursor proteins: proopiomelanocortin (POMC), prodynorphin (PDYN) and proenkephalin (PENK) (Table 1). POMC is a precursor for $\alpha$ - and $\beta$-endorphin and non-opioid peptides, such as adrenocorticotropic hormone (ACTH), $\alpha$ - and $\beta$-melanocytestimulating hormone (MSH), corticotropin-like intermediate peptide (CLIP) and $\beta$-lipotropin ( $\beta$-LPH). Dynorphin $\mathrm{A}$ and $\mathrm{B}$ and neomorphins derive from PDYN. PENK is a precursor for enkephalins ([Leu $\left.{ }^{5}\right]$ enkephalin, $\left[\mathrm{Met}^{5}\right]$ enkephalin, $\left[\mathrm{Met}^{5}\right]$ enkephalin- $\mathrm{Arg}^{6}-\mathrm{Gly}^{7}-\mathrm{Leu}^{8}$, and $\left[\mathrm{Met}^{5}\right]$ enkephalin- $\mathrm{Arg}^{6}-\mathrm{Phe}^{7}$ ). Bovine adrenal medulla (BAM) peptide and peptides $\mathrm{E}$ and $\mathrm{F}$ are further products formed from PENK [70].

Opioid peptides are an important link between the neuroendocrine and immune systems, and their immunomodulatory effect may play a significant clinical role in immune-mediated diseases.

Endogenous opioid peptides have been reported to inhibit the release of neurotransmitters, such as ACh, dopamine, norepinephrine in the CNS and in the periphery. There are many studies reporting the effects of endogenous opioids on human body, like control of nociception, mood, and cardiovascular functions, which have been extensively reviewed elsewhere [71-73]. Here, we discuss the effect of endogenous opioids in the GI tract and their possible role in the GI physiology and function.

In the GI tract the endogenous opioid peptides are present both in neurons and endocrine cells of the mucosa [11, 74]. Under physiological conditions, endogenous opioid peptides exert inhibitory effect on gastric emptying and intestinal motility. Opioid peptides also decrease biliary, pancreatic and intestinal secretions [75].

\section{Enkephalins}

Enkephalins are short peptides, which are produced mainly by the pituitary, adrenal glands and the pancreas. In the GI tract enkephalins are also formed in gastric and intestinal endocrine cells [76]. There are two enkephalins, which play a major role in molecular signaling through opioid receptors, $\left[\mathrm{Leu}^{5}\right]$ enkephalin and $\left[\mathrm{Met}^{5}\right]$ enkephalin. Both peptides are potent DOR agonists, and additionally possess some affinity at MOR. The major physiological effect of enkephalins is antinociception and inhibition of pain signaling in the CNS and the periphery, including the GI tract $[11,74]$.

Enkephalins were also found to be synthesized in leukocytes and may thus participate in inflammatory response. Owczarek et al. [77] found recently that the serum level of $\left[\mathrm{Met}^{5}\right]$ enkephalin were decreased in patients with inflammatory bowel diseases (IBD) in comparison to healthy volunteers. Higher levels of [ $\left.\mathrm{Met}^{5}\right]$ enkephalin were found in colonic biopsies collected from inflammatory lesions from patients with IBD, compared to biopsies from noninflamed colon.

DAMGO, a synthetic MOR agonist, which structure is based on enkephalin, was studied in a rat model of visceral pain (i.p. and i.c.v. injections of $2 \%$ acetic acid) and compared to morphine. I.c.v. injection of DAMGO was more potent than morphine injection in the reduction of pain. Moreover, administration of naloxone methiodide, a peripherally acting antagonist, attenuated the antinociceptive action of DAMGO and morphine [78]. In another study DAMGO was reported to induce suppression of enhanced excitability of colon dorsal root ganglion neurons from rats with chronic visceral hyperalgesia, an animal model used to characterize mechanisms related to irritable

Table 1 Sequences and affinity of endogenous and exogenous opioid peptides

\begin{tabular}{|c|c|c|c|}
\hline Precursor & Peptide & Sequence & Receptor affinity \\
\hline $\begin{array}{l}\text { Pro- } \\
\text { opiomelanocortin }\end{array}$ & $\beta$-endorphin & $\begin{array}{l}\text { Tyr-Gly-Gly-Phe-Met-Thr-Ser-Glu-Lys-Ser-Gln-Thr-Pro-Leu-Val-Thr-Leu- } \\
\text { Phe-Lys-Asn-Ala-Ile-Ile-Lys-Asn-Ala-Tyr-Lys-Lys-Gly-Glu }\end{array}$ & $\mathrm{MOR}>\mathrm{DOR}>\mathrm{KOR}$ \\
\hline Pro-enkephalin & $\begin{array}{l}{\left[\mathrm{Met}^{5}\right] \text { Enkephalin }} \\
{\left[\mathrm{Leu}^{5}\right] \text { Enkephalin }}\end{array}$ & $\begin{array}{l}\text { Tyr-Gly-Gly-Phe-Met } \\
\text { Tyr-Gly-Gly-Phe-Leu }\end{array}$ & $\mathrm{DOR}>\mathrm{MOR} \gg \mathrm{KOR}$ \\
\hline Pro-dynorphin & $\begin{array}{l}\text { Dynorphin A } \\
\text { Dynorphin B } \\
\alpha \text {-neomorphin } \\
\beta \text {-neomorphin }\end{array}$ & $\begin{array}{l}\text { Tyr-Gly-Gly-Phe-Leu-Arg-Arg-Ile-Arg-Pro-Lys-Trp-Asp-Asn-Gln } \\
\text { Tyr-Gly-Gly-Phe-Leu-Arg-Arg-Gln-Phe-Lys-Val-Val-Thr } \\
\text { Tyr-Gly-Gly-Phe-Leu-Arg-Lys-Tyr-Pro-Lys } \\
\text { Tyr-Gly-Gly-Phe-Leu-Arg-Lys-Tyr-Pro }\end{array}$ & $\mathrm{KOR} \gg \mathrm{MOR}>\mathrm{DOR}$ \\
\hline Unknown & $\begin{array}{l}\text { Endomorphin-1 } \\
\text { Endomorphin-2 }\end{array}$ & $\begin{array}{l}\text { Tyr-Pro-Trp-Phe- } \mathrm{NH}_{2} \\
\text { Tyr-Pro-Phe-Phe- } \mathrm{NH}_{2}\end{array}$ & $\begin{array}{l}\text { MOR } \\
\text { MOR }\end{array}$ \\
\hline$\kappa$-casein & Casoxin 4 & Tyr-Pro-Ser-Tyr-OCH ${ }_{3}$ & MOR \\
\hline$\beta$-conglycinin & $\begin{array}{l}\text { Soymorphin-5 } \\
\text { Soymorphin-6 } \\
\text { Soymorphin-7 }\end{array}$ & $\begin{array}{l}\text { Tyr-Pro-Phe-Val-Val } \\
\text { Tyr-Pro-Phe-Val-Val-Asn } \\
\text { Tyr-Pro-Phe-Val-Val-Asn-Ala }\end{array}$ & MOR \\
\hline
\end{tabular}


bowel syndrome (IBS), induced by i.c. injection of acetic acid [79].

\section{Endomorphins}

Endomorphin-1 (EM-1, Tyr-Pro-Trp-Phe- $\mathrm{NH}_{2}$ ) and EM-2 (Tyr-Pro-Phe-Phe- $\mathrm{NH}_{2}$ ) are two endogenous tetrapeptides isolated by Zadina et al. [80] from the bovine frontal cortex and human brain. EMs possess the highest affinity at MOR of all known endogenous agonists.

There are several reports on the activity of EMs in the GI tract. It was demonstrated that EM-1 and EM-2 inhibited striated and smooth muscle response in the esophagus (with exception of lower esophageal sphincter) in a naloxonereversible manner [81]. In the guinea pig ileum, EMs decreased the release of ACh in LMMP preparations [82, 83].

Furthermore, EMs inhibited longitudinal muscle contractions in the mouse distal colon and evoked contractile response in circular muscle of proximal and mid colon. It was also observed that $\beta$-FNA $\left(3 \times 10^{-6}\right)$ and naloxonazine $\left(10^{-6}\right)$ abolished EM-1-induced contractions, suggesting the involvement of MOR receptor subtypes in contractile responses induced by EM-1 [84].

Some studies suggest an immunomodulatory role of EMs in the GI tract. The effect of EM-2 on rat peritoneal macrophage function was investigated by Azuma et al. [85], who showed that EM-2 inhibited the production of cytokines, including TNF- $\alpha$, IL-10 and IL-12. In addition, EM-2 increased IL-1 $\beta$ production in phorbol 12-mirystate 13-acetate (PMA)-stimulated macrophages and inhibited chemotaxis.

EMs, similarly to other endogenous opioid peptides, are prone to rapid degradation and, therefore, studies on their role in the GI tract are limited. Recently, several new EM analogs with improved pharmacological profile and biodistribution were reported (for review see: [86]). One of the novel analogs, obtained by the attachment of lactose to the $\mathrm{N}$-terminus of EM via a succinamic acid spacer, showed improved membrane permeability and increased metabolic stability [87]. Interestingly, the adverse effects of this modified EM on stool hydration, measured using a castor oil-induced diarrhea assay and GI motility, assessed using a charcoal GI transit test were less significant compared to morphine administration. Furthermore, delayed transit was not observed in rodents treated with the new compound. The attractive additional benefit of this modified EM was that it may be administered orally.

Other opioids

\section{Peptides and their derivatives}

Soymorphins. The soymorphins, mainly soymorphin-5, -6, and -7 (Table 1), are MOR agonists, which were shown to suppress food intake and intestinal motility after oral administration in a naloxone-dependent manner [88]. The inhibitory potency of soymorphins on the GI transit was assessed using selective agonists and antagonists of $5 \mathrm{HT}_{1 \mathrm{~A}}$ (WAY100135), $\mathrm{D}_{2}$ (raclopride) and $\mathrm{GABA}_{\mathrm{B}}$ (saclofen) receptors. The obtained results suggest that soymorphins inhibit small intestinal motility through the release of serotonin and activation of $5-\mathrm{HT}_{1 \mathrm{~A}}$ receptors. Then, dopamine is released and acts via $D_{2}$ receptors. Finally, GABA is released, which acts through $\mathrm{GABA}_{\mathrm{B}}$ receptors.

Casoxin 4. Casoxin 4 is a tetrapeptide MOR antagonist, which was isolated from the $\mathrm{\kappa}$-casein fraction of bovine milk (Table 1). It was demonstrated that casoxin-4 reversed morphine-induced inhibition of electrically induced contraction in isolated small intestine in both mice and guinea pigs [89]. The MOR component was more prominent in the guinea pig ileum, while KOR and DOR components were predominant in the mouse ileum. Casoxin 4 after oral administration failed to attenuate the inhibitory effect of morphine in the murine small intestine. [90].

\section{Alkaloids and diterpenes}

Morphine. Morphine is a classical opioid analgesic commonly used for the treatment of acute and chronic pain. Its major site of action is MOR, but it also displays a minor affinity at KOR. Morphine can cross the BBB and act in the CNS. Therefore, its prolonged and repetitive administration may cause tolerance, nausea, or sedation [91]. Here we focus on the beneficiary and adverse effects of morphine in the GI tract.

Morphine delays GI transit in a MOR-dependent manner, but it remains a matter of debate whether this effect is mediated by MOR in the CNS, the periphery or both. Chronic administration of morphine $(0.05 \mathrm{mg} / \mathrm{kg}$, s.c. $)$ in healthy human volunteers caused delayed colonic transit time. Interestingly, the administration of naloxone-3glucuronide $(0.16 \mathrm{mg} / \mathrm{kg}$, p.o.), a naloxone metabolite, reversed the effect of morphine without any impact on analgesia [92]. Naloxone-3-glucuronide is not absorbed into systemic circulation, there is no penetration through the colonic-mucosal blood barrier. This suggests that the action of opioids in the GI tract is mediated mainly by peripheral receptors. Highly polar naloxone derivatives peripherally antagonize the effect of morphine-delayed GI motility in the perfused isolated rat colon [93]. However, some studies imply that only the CNS is involved.

The development of tolerance following repeated exposition to morphine is well defined at the cellular and molecular level, but is poorly understood in vivo, in particular in terms of GI function. Chronic administration of 
morphine may produce tolerance in the upper GI tract, specifically in the circular muscle in the ileum, but not in the colon [94]. The lack of tolerance to morphine observed in the colon may underlie constipation and the development of the opioid-induced bowel dysfunction (OBD).

It was suggested that a transport protein, glycoprotein $\mathrm{P}$, might be involved in the development of opioid tolerance, but its role has not been clearly identified [95-97]. Okura et al. [98] showed that repeated administration of morphine in rats reduced intestinal absorption of morphine, subsequently decreasing its antinociceptive effects. The decrease in absorption was related, at least partially, to the stimulation of glycoprotein P-mediated efflux. The up-regulation of glycoprotein P may thus contribute to the development of opioid tolerance to morphine and oxycodone after oral administration. Therefore, the design of opioids without glycoprotein $\mathrm{P}$ substrate activity might be a key to avoid the development of tolerance during their chronic administration.

Morphine and other alkaloids may be involved in the immune response mediated by the opioid receptors in the GI tract. Peng et al. [99] showed that s.c. implementation of a morphine slow release pellet suppressed cholera toxinspecific production of $\operatorname{IgA}$ and $\operatorname{IgG}$ in fragment cultures of ileal segments, Peyer's patches and mesenteric lymph nodes. It was also found that the effect of morphine in gutassociated lymphoid tissue was mediated through a TGF- $\beta$, a putative $\operatorname{IgA}$ switch factor in the GI tract-dependent pathway. The inhibition of TGF- $\beta$ by morphine was reversed by naltrexone, which confirms an involvement of opioid receptors in immune responses in the GI tract.

Furthermore, morphine may be involved in the development of bacterial infections, induced by Streptococcus pneumonia, Toxoplasma gondii, Klebisella pneumonia, Candida albicans and other bacterial strains. Interestingly, these infections promoted by morphine were shown to be dependent on MOR [100]. Feng et al. demonstrated that implementation of $75 \mathrm{mg}$ slow release morphine pellet in mice was a potent enhancer of an oral infection with Salmonella typhimurium, which is used to induce a murine model of typhoid fever and causes gastroenteritis in humans. Morphine administered via minipumps (at doses $1-25 \mathrm{mg} / \mathrm{kg} /$ day) did not sensitize to Salmonella infection and inhibited GI transit more potently than the morphine pellets [101].

Chronic administration of morphine in mice may cause alterations in virulence expression in Pseudomonas aeruginosa and lead to lethal gut-derived sepsis [102]. The expression of virulent phenotype against intestinal epithelium (strain of Pseudomonas aeruginosa disrupting protein PA-I lectin) in response to morphine may be principally mediated by MOR. However, since a peripherally restricted MOR antagonist MNTX did not delay chemotaxis after
Pseudomonas challenge, it is possible that morphine may also act on other receptors, including non-opioid.

Interestingly, Glattard et al. [103] hypothesized that endogenous morphine, which is secreted from human neutrophils following stimulation by lipopolysaccharide (LPS) and IL-8 in presence of $\mathrm{Ca}^{2+}$, may be involved in inflammatory responses. They have also shown that the endogenous morphine level is elevated in patients with sepsis.

Salvinorin A. Salvinorin A (SA), a diterpene isolated from the Mexican plant Salvia divinorum, is a selective KOR agonist, which displays significant inhibitory and anti-inflammatory effects in the GI tract. It was observed that in physiological conditions SA inhibited cholinergic twitch contractions in mouse and guinea pig small and large intestine in a KOR- and CB1-dependent manner [104, 105]. Furthermore, SA reversed ileal hypermotility induced by croton oil [106] or endotoxin [107] administration in mice. Interestingly, in this latter model the regulatory action of SA on epithelial barrier function was mediated via NO-related pathways. Recently our group showed that SA exhibits anti-inflammatory and anti-nociceptive effects in murine models of intestinal inflammation [108].

The pharmacology of SA in the GI tract was recently reviewed [109].

\section{Opioid system in pathophysiological conditions of the GI tract}

\section{Diarrhea}

The inhibitory effects of opioids in the GI tract, such as inhibition of neuronal activity, reduced propulsion and delay of GI transit have been used for centuries for example to treat diarrhea. Diarrhea is a change of normal bowel movement characterized by an increase in the water content, volume, or frequency of stools.

The classical anti-diarrheal agent, loperamide (Fig. 5), is an agonist of a putative MOR subtype, which is expressed in peripheral organs [110]. Loperamide is widely used in patients with digestive disorders and after radiotherapy and chemotherapy to control diarrhea. It has poor capacity for BBB penetration at concentrations required for anti-diarrheal effect [56]. In the GI tract loperamide causes intestinal relaxation, which is triggered by the opening of ATP-sensitive potassium channels. The activation of $\mathrm{K}^{+}$ channels triggers cAMP-PKA signaling pathways, which induce hyperpolarization of cell membranes and relaxation of smooth muscles. Opening of ATP-sensitive channels also reduces concentration of intracellular $\mathrm{Ca}^{2+}$, which is similar to that observed in OIC [111]. Finally, loperamide 

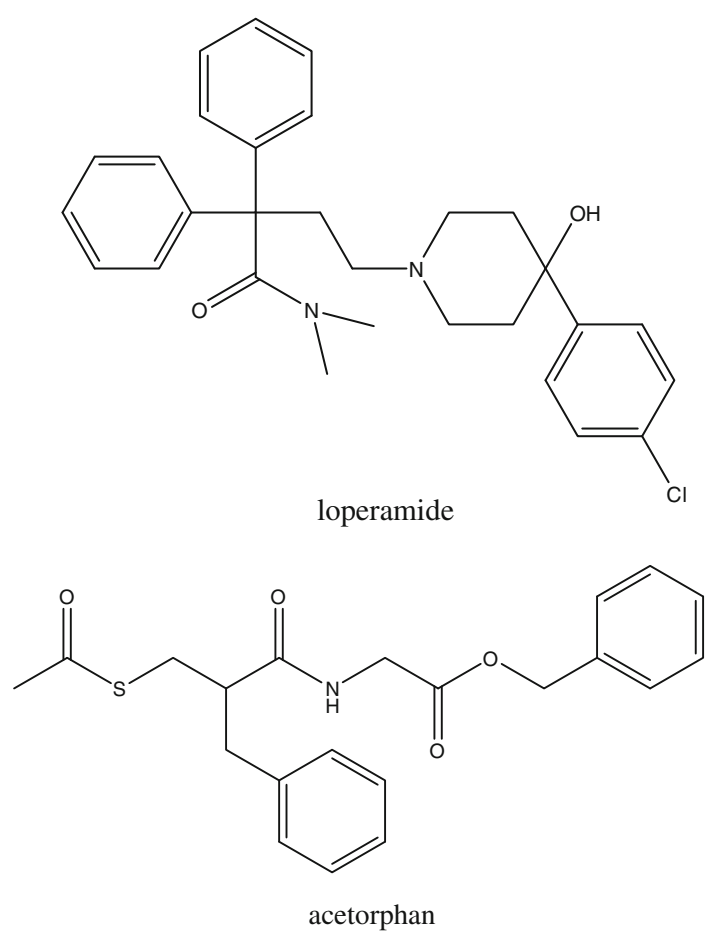

Fig. 5 Structures of anti-diarrheal agents, loperamide and acetorphan

injected intrathecally induces MOR-mediated analgesia [112].

Acetorphan (Racecadotril) (Fig. 5) is another drug used in the treatment of acute or chronic diarrhea. Similarly to loperamide, acetorphan does not cross BBB. However, it displays a different mechanism of action, since it does not affect gut motility [113]. The anti-diarrheal effect of acetorphan results from inhibition of enkephalinases, proteolytic enzymes degrading endogenous opioids present in the GI tract. Acetorphan increases concentration of endogenous opioids in the GI tract and reduces secretion of electrolytes and water into the gut lumen.

The possible application of opioids in different types of diarrhea has been suggested. The role of opioid receptors and their ligands in murine allergic diarrhea has been studied by Duncker et al. [114]. They observed that the ovalbumin (OVA)-induced allergic diarrhea was improved by DAMGO and U50'488, synthetic agonists of MOR and KOR, respectively. Moreover, DAMGO decreased concentration of IFN- $\gamma$, IL-4, IL-5 and IL-10 after ex vivo stimulation of mesenteric lymphocytes. In comparison with U50' 488, DAMGO did not decrease plasma level of mouse mast cell protease-1 (MMCP-1), which is a marker of mast cell degranulation or total plasma IgE. Interestingly, thymoquinone-lipophilic compound in hexanic extract from Nigella sativa (Black cumin) also exhibited beneficial effects in allergic diarrhea by activation of opioid receptors. The thymoquinone exhibited anti-inflammatory and anti-cancer properties and was involved in alleviation of allergic asthma [115-117]. The results of the study suggest that opioid receptor-mediated modulation of GI and immune systems may become a target for future therapies aiming at alleviation of allergy-based diarrhea symptoms.

Opioid agonists, such as trimebutine or loperamide are commonly used for treatment of symptoms in diarrheapredominant IBS (IBS-D). However, their pharmacological profile seems less favourable compared to $5-\mathrm{HT}_{3}$ antagonists $\left(5-\mathrm{HT}_{3} \mathrm{RAs}\right)$, like ramosetron, alosetron and cilansetron. As shown by Hirata et al. [118], 5-HT ${ }_{3}$ RAs increased colonic nociceptive threshold in non-stressed rats, and also inhibited restraint-induced colonic hyperalgesia and diarrhea. The latter effect was not achieved in rats treated with loperamide [118].

\section{Opioid-induced bowel dysfunction}

Chronic administration of opioids, in particular at high doses, may cause several adverse side effects, mainly originating in the GI tract (for review see: McNicol [119]). The major opioid-related group of GI disorders, described as OBD, affects up to $10-20 \%$ of adolescents and adults around the world [120].

Several ailments characterize OBD, such as constipation, abdominal pain, bloating and gastro-esophageal reflux. The chronic occurrence of OBD symptoms may cause nausea, fecal impaction, vomiting and critical disturbances in absorption of concomitant drugs. Vomiting and nausea may lead to further complications, including pneumonia, while mitigated oral intake can be associated with malnutrition. Abdominal distention associated with OBD may affect respiratory function and delay wound healing [121].

One of the most common side effects resulting from chronic administration of opioids is constipation. It is defined as a delay in frequency of intestine movements and is often accompanied by other symptoms, such as hard and dry stools, incomplete bowel movements, or straining during defecation. Since constipation is not always related to OBD, an additional term for this ailment, OIC, was introduced [75]. OIC is an adverse side effect of opioid administration, but some additional factors may influence its development, e.g. metabolic disorders, including diabetes mellitus, hypokalemia, hypercalcemia, and hypothyreodism, advanced age, low-fluid intake, or reduced physical activity ([122], for review see: [123]).

The mechanism of OIC is complex and implies many factors, but the activation of opioid receptors in the periphery is critical. In general, opioids induce constipation through disruption of neurotransmission between enteric neurons and their targets-smooth muscles and epithelial cells [44]. The activation of opioid receptors results in a 
depression of peristaltic contractions, but also in an increase of GI muscle activity, like increase of resting muscle tones of sphincters, non-propulsive patterns and spasms. In addition, opioids increase biliary and internal anal sphincter tones. Finally, suppression of ongoing discharge in secretomotor neurons in the ENS, resulting in the inhibition of basal epithelial secretion and increased absorption of fluids from the intestine, which evoke dry and hard stools, may also contribute to development of OIC [124].

The treatment of OIC involves the use of stimulant laxatives, stool softeners and osmotic agents, but this classical therapy is often not effective. Lubiprostone (Fig. 6), which is used in clinical conditions to suppress the symptoms of OIC and constipation predominant-IBS, is a bicyclic fatty acid of prostone group and derives from prostaglandin E1 [125]. Lubiprostone reverses inhibitory action of opioids on mucosal secretion in human small intestine by promoting transcellular movement of $\mathrm{Cl}^{-}$from serosal to luminal area in mucosal epithelia, which enhances fluid secretion [126]. The driving force for this increased transport of $\mathrm{Cl}^{-}$into intestinal lumen is provided by $\mathrm{Na} / \mathrm{K}$ pump, with $\mathrm{Cl}^{-}$entering the cell across basolateral membrane through $\mathrm{Na}-\mathrm{K}-2 \mathrm{Cl}$ co-transporter and other channels on apical membrane. It was shown that lubiprostone evokes $\mathrm{Cl}^{-}$secretion via cystic fibrosis transmembrane conductance regulator (CFTR) receptors and cAMP signaling in human T84 colon cancer cell line. Furthermore, the transport of $\mathrm{Cl}^{-}$is dose-dependent and inhibited by a CFTR inhibitor [127]. Lubiprostone thus increases mucosal secretion and liquidity of bowel contents and enables the avoidance or resolution of OIC by chloride channels without influencing the opioid receptors [128], which was confirmed in the studies on mice and guinea pigs [129]. However, therapy with lubiprostone is associated with side effects including nausea, diarrhea, abdominal pain and bloating [130].

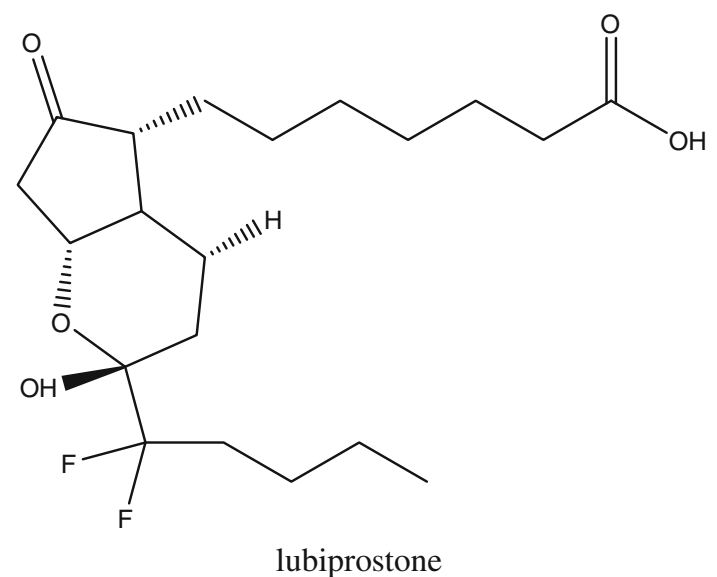

Fig. 6 Structure of lubiprostone
Postoperative ileus

Postoperative ileus (POI) is a transient cessation of coordinated bowel function following surgical interventions [131]. POI is a common complication, which occurs mainly after abdominal, orthopaedic, or cardiac surgery and affects the whole GI tract. POI may be triggered by symphatetic reflexes, inhibitory humoral agents, release of noradrenaline from gut wall, anaesthesic agents and inflammation. Furthermore, POI is often induced by enteric inflammatory response and recruitment of leukocytes to muscularis of intestine wall, which are responsible for production of NO, a major inhibitory neurotransmitter in the GI tract. The levels of prostaglandins, upon cyclooxygenase-2 (COX-2) and inducible NO synthase (iNOS) activation, as well as cytokines, including TNF- $\alpha$, IL-1 $\beta$ and IL-6 may also increase in POI [132].

The clinical symptoms of POI are similar to those in OBD, including abdominal distention, lack of intestinal movements, and accumulation of gas and fluids in the intestine. The inhibition of gut motility occurs immediately after surgery, persists for 2-3 days and resolves spontaneously. However, delayed GI recovery may lead to clinically relevant complications, such as poor nutritional intake, delayed wound healing, infections or pulmonary dysfunction [133] and impact the time of patient hospitalization.

Opioid agonists, which are used for the treatment of post-operative pain, may negatively contribute to POI by stimulation of MOR in the GI tract and inhibition of intestinal motility [134], as well as activation of iNOS and increase in NO release from phagocytes. The major purpose of peripherally acting MOR antagonist (PAMORA) administration is the mitigation of adverse side effects of endogenous and exogenous opioids in periphery with maintenance of analgesic effect in the CNS, mainly due to a low BBB permeability at therapeutic concentrations (Fig. 7). There are two drugs on the market that are used in the management of POI after resection of intestine, alvimopan and methylnatrexone (MNTX) (Fig. 8). Both were approved by the Food and Drug Administration (FDA) and the European Medicine Agency in 2008 for the treatment of OBD and POI. The critical difference between both drugs is in their utility: alvimopan is applied to treat opioid-naïve, while MNTX opioid-treated patients. Furthermore, alvimopan can be administrated only up to 8 days due to the possibility of myocardial events [135].

Alvimopan. Alvimopan is approximately 200 times more potent at peripheral than central MOR [136]. Acute administration of alvimopan is used to accelerate the time to recovery of upper and lower GI after abdominal surgery. Chronic administration at low doses reverses OBD and 


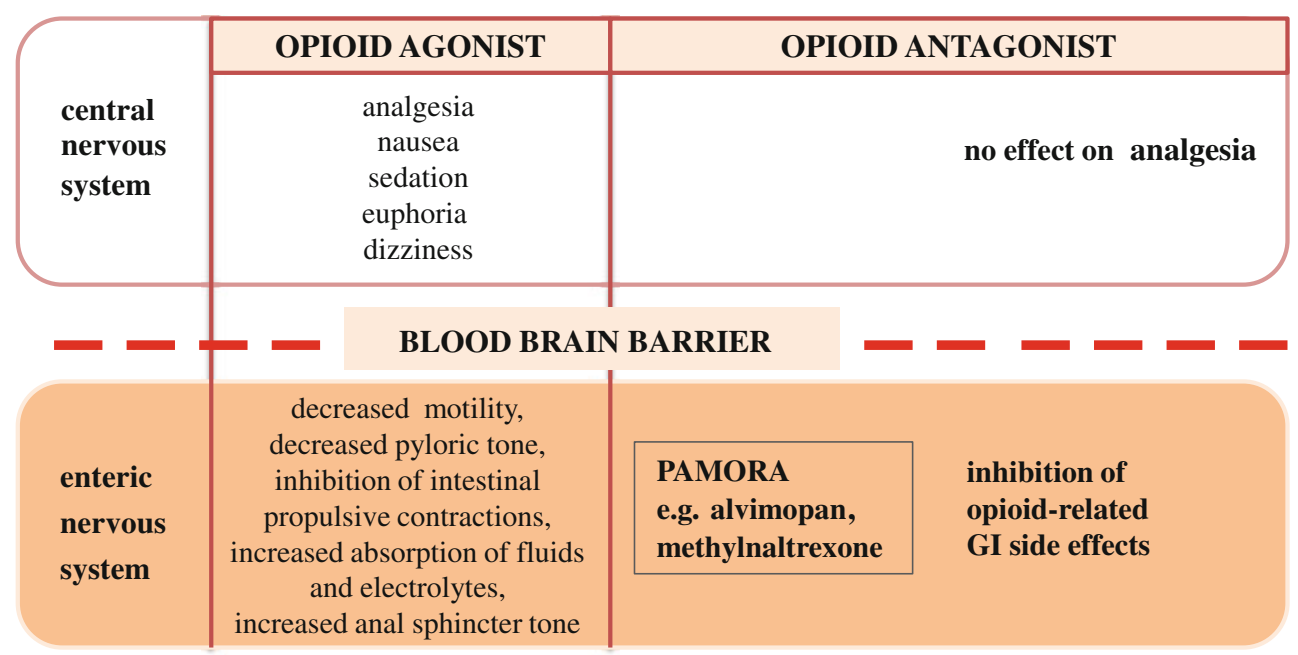

Fig. 7 Principle of action of peripherally acting MOR antagonists (PAMORA)<smiles>C[C@H]1CN(C[C@H](Cc2ccccc2)C(=O)NCC(=O)O)CC[C@]1(C)c1cccc(O)c1</smiles>

alvimopan

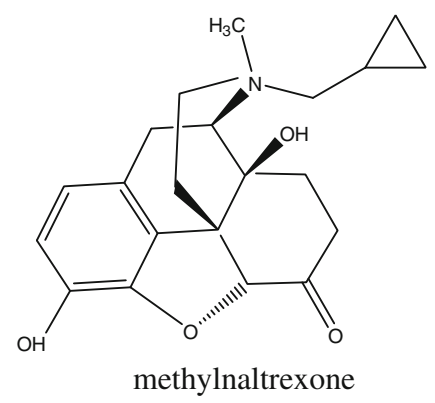

Fig. 8 Structures of clinically used peripherally acting MOR antagonists (PAMORA): alvimopan and methylnaltrexone

OIC [137]. Furthermore, alvimopan reduces opioidinduced nausea and vomiting [138].

Earlier clinical trials with alvimopan were reviewed by Marderstein et al. [139] and the most recent ones are summarized in Table 2.

In 2008 a randomized, double-blind, placebo-controlled, dose-finding study was performed on 522 non-cancer humans with $<3$ spontaneous bowel movements per week and other complications associated with chronic opioid administration ( $>30 \mathrm{mg}$ of morphine/day), which were maintained over 6 weeks [140]. After 3 weeks all patients treated with alvimopan $(0.5$ or $1.0 \mathrm{mg}$ once or twice a day, p.o.) exhibited improvement in spontaneous bowel movements and all additional complications.
The post hoc analysis of four randomized, double-blind, placebo controlled, phase III trials showed a beneficial impact of alvimopan on GI recovery in 1409 patients after bowel resection [150]. Of patients orally treated with alvimopan $(12 \mathrm{mg}$ at least $30 \mathrm{~min}$, but no longer than $5 \mathrm{~h}$ before surgical intervention), $80 \%$ exhibited GI recovery on or before 5 postoperative days. Moreover, the GI recovery and discharge from hospital were improved in comparison to placebo-controlled patients.

The randomized, placebo controlled phase III trial of alvimopan for OIC treatment in 512 patients with nonchronic pain demonstrated that oral administration of alvimopan once or twice a day improved bowel movements in comparison with placebo group [142]. Moreover, treatment for 12 weeks was tolerant and safe for all patients treated with alvimopan. The administration of additional drugs, e.g. laxatives, was not required.

The length of stay in hospital of patients with laparoscopic partial colectomies, in which standard postoperative treatment was aided by alvimopan $(12 \mathrm{mg}$ before and $6 \mathrm{mg}$ twice a day, for max. 7 days after surgery) was significantly shorter compared with control group [151, 152].

Finally, the large-scale report of alvimopan used in treatment of 3525 patients after open or laparoscopic bowel resection revealed that the administration of alvimopan reduced the length and costs of hospitalization [153]. Lower incidence of GI morbidity, mortality and intensive care unit (ICU) stay were also reported.

In 2008 Schmidt et al. [136] evaluated the action of alvimopan in the presence of the COX-2 inhibitor DFU in a rodent model of POI. Alvimopan $(10 \mathrm{mg} / \mathrm{kg}$, s.c.) reversed morphine $(1 \mathrm{mg} / \mathrm{kg})$-induced delay in the GI transit, but had no effect on transit in control animals. In addition, the morphine-induced delay of the GI transit was not observed in mice pretreated with alvimopan. The co-administration 
Table 2 Summary of clinical trials for alvimopan

\begin{tabular}{|c|c|c|c|c|c|}
\hline $\begin{array}{l}\text { Study } \\
\text { design }\end{array}$ & $\begin{array}{l}\text { No. of } \\
\text { patients }\end{array}$ & Participants & Dose $^{\mathrm{a}}$ & Conclusions & $\overline{\text { References }}$ \\
\hline $\begin{array}{l}\mathrm{DB}, \mathrm{R} \\
\mathrm{P}-\mathrm{C}\end{array}$ & 522 & $\begin{array}{l}\text { Patients with OBD and non-cancer } \\
\text { chronic pain with morphine } \\
\text { administration }>30 \mathrm{mg} / \text { day }\end{array}$ & $\begin{array}{l}0.5 / 1 \mathrm{mg} Q \mathrm{QD}, \mathrm{BID} \\
6 \text { weeks }\end{array}$ & $\begin{array}{l}\text { Restoration of GI function and } \\
\text { attenuation of OBD symptoms }\end{array}$ & [140] \\
\hline $\begin{array}{l}\text { DB, R, } \\
\text { P-C }\end{array}$ & 168 & $\begin{array}{l}\text { Patients with OBD, non-cancer pain and } \\
\text { opioid treatment }\end{array}$ & 0.5/1 mg QD, 3 weeks & No effect on opioid-induced analgesia & [141] \\
\hline $\begin{array}{l}\text { DB, R, } \\
\text { P-C }\end{array}$ & 518 & Patients with OBD and non-cancer pain & $\begin{array}{l}0.5 / 1 \mathrm{mg} Q \mathrm{QD}, \mathrm{BID} \\
12 \text { weeks }\end{array}$ & $\begin{array}{l}\text { No effect on the requirement for opioid } \\
\text { medication }\end{array}$ & [142] \\
\hline $\begin{array}{l}\text { DB, R, } \\
\text { P-C }\end{array}$ & 485 & Patients with OBD and non-cancer pain & $\begin{array}{l}0.5 / 1 \mathrm{mg} Q \mathrm{QD}, \mathrm{BID} \\
12 \text { weeks }\end{array}$ & Attenuation of OBD symptoms & [143] \\
\hline $\begin{array}{l}\text { DB, R, } \\
\text { P-C }\end{array}$ & 469 & Patients after surgery & $\begin{array}{l}6 / 12 \mathrm{mg}>2 \mathrm{~h} \text { before } \\
\text { surgery, then BID, } \\
\text { max. } 1 \text { week }\end{array}$ & Acceleration in recovery of GI function & [144] \\
\hline $\begin{array}{l}\mathrm{DB}, \mathrm{R} \\
\mathrm{PG} \\
\mathrm{P}-\mathrm{C}\end{array}$ & 615 & Patients after surgery & $\begin{array}{l}6 / 12 \mathrm{mg}>2 \mathrm{~h} \text { before } \\
\text { surgery, then BID, } \\
\text { max. } 1 \text { week }\end{array}$ & $\begin{array}{l}\text { Acceleration in recovery of GI transit in } \\
\text { patients after laparotomy }\end{array}$ & [145] \\
\hline $\begin{array}{l}\mathrm{DB}, \mathrm{R} \\
\mathrm{PG} \\
\mathrm{P}-\mathrm{C}\end{array}$ & 911 & Patients after surgery & $\begin{array}{l}6 / 12 \mathrm{mg}>2 \mathrm{~h} \text { before } \\
\text { surgery, then BID, } \\
\text { max. } 1 \text { week }\end{array}$ & $\begin{array}{l}\text { Potential benefit in bowel resection } \\
\text { patients who received i.v. patient- } \\
\text { controlled analgesia }\end{array}$ & {$[146]$} \\
\hline $\begin{array}{l}\text { R, PG, } \\
\text { P-C }\end{array}$ & 78 & Patients after surgery & $\begin{array}{r}1 / 6 \mathrm{mg}>2 \mathrm{~h} \text { before } \\
\text { surgery, then BID }\end{array}$ & Shorter duration of hospitalization & [147] \\
\hline $\begin{array}{l}\text { DB, R, } \\
\text { P-C }\end{array}$ & 654 & Patients after surgery & $\begin{array}{l}12 \text { mg } 30-90 \text { before } \\
\text { surgery, then BID, } \\
\text { max. 1 week }\end{array}$ & $\begin{array}{l}\text { Reduction in POI-related morbidity } \\
\text { without compromising opioid } \\
\text { analgesia }\end{array}$ & [148] \\
\hline $\begin{array}{l}\text { DB, R, } \\
\text { P-C }\end{array}$ & 519 & Patients after surgery & $\begin{array}{l}12 \mathrm{mg}>2 \mathrm{~h} \text { before } \\
\text { surgery then BID, } \\
\text { max. } 1 \text { week }\end{array}$ & $\begin{array}{l}\text { Improvement in lower GI recovery in } \\
\text { women }\end{array}$ & [149] \\
\hline
\end{tabular}

${ }^{a}$ In all trials alvimopan was administered p.o.

$D B$ double-blind, $R$ randomized, $P G$ parallel group, $P-C$ placebo-controlled, $Q D$ once daily, $B I D$ twice daily

of alvimopan with DFU inhibited the immunosuppressive action of morphine, suggesting a new strategy for the treatment of inflammatory response in postoperative inflamed GI tissues.

Recently, Vaughan-Shaw et al. [154] performed a metaanalysis, which comprises three clinical studies mentioned above [144, 145, 150]. This meta-analysis showed that $12 \mathrm{mg}$ of alvimopan p.o. given $2 \mathrm{~h}$ before surgery and than twice a day until discharge significantly accelerates recovery of GI tract and reduces time to hospital discharge in patients undergoing open abdominal surgery enrolled in an Accelerated Recovery Program.

Methylnatrexone (MNTX). MNTX, similarly to alvimopan, antagonizes MOR located in the intestine without any effect on opioid receptors present in the CNS. MNTX is less selective at MOR than alvimopan, as it also binds at KOR [155].

The clinical trials for MNTX are summarized in Table 3. In a randomized, parallel-group, double-blind, placebo-controlled trial of 48 healthy human volunteers, $\operatorname{MNTX}(0.3 \mathrm{mg} / \mathrm{kg} /$ day, s.c. $)$ did not induce any changes in the GI transit in comparison to placebo [156]. Moreover,
MNTX did not reverse the anti-motility action of codeine (120 mg/kg/day, for 5 consecutive days).

The clinical efficiency of MNTX was evaluated in patients with OIC and chronic, non-malignant pain in a double-blind, randomized, placebo controlled study [159]. In this trial patients received MNTX (12 mg, s.c.), every day, every other day (alternatively with placebo) or placebo alone for 4 weeks. Roughly $40 \%$ of patients reported rescued free bowel movements (RFBM) after $\geq 2$ of four doses of MNTX, while $30 \%$ had more than 3 RFBMs per week of MNTX administration. In another study with a larger group of patients (460) exhibiting OIC in advanced illness, $34 \%$ of patients had RFBMs within $4 \mathrm{~h}$ after the first dose of MNTX [161]. In the placebo group only $10 \%$ patients had RFBMs. The adverse effects during MNTX treatment were minimal-the most common was abdominal pain and the drug was safe and tolerated by all patients.

Another randomized, double-blind, parallel group, placebo-controlled study revealed no improvement of life quality in postcolectomy patients treated with MNTX or placebo [162]. The drug was intravenously administered in 
Table 3 Clinical trials for methylnaltrexone

\begin{tabular}{|c|c|c|c|c|c|c|}
\hline $\begin{array}{l}\text { Study } \\
\text { design }\end{array}$ & $\begin{array}{l}\text { No. of } \\
\text { patients }\end{array}$ & Participants & Drug dose & $\begin{array}{l}\text { Route of } \\
\text { administration }\end{array}$ & Conclusions & References \\
\hline $\begin{array}{l}\mathrm{DB}, \mathrm{R}, \\
\mathrm{PG}, \\
\mathrm{P}-\mathrm{C}\end{array}$ & 48 & Healthy humans & $0.3 \mathrm{mg} / \mathrm{kg}, 1$ week & s.c., p.o. & $\begin{array}{l}\text { No effect on delayed GI } \\
\text { transit }\end{array}$ & {$[156]$} \\
\hline $\begin{array}{l}\text { DB, R, } \\
\text { P-C }\end{array}$ & 12 & & & & & \\
\hline $\begin{array}{l}\text { DB, R, } \\
\text { P-C }\end{array}$ & 11 & & $\begin{array}{l}0.09 \mathrm{mg} / \mathrm{kg} \\
\text { morphine }+0.3 \mathrm{mg} / \\
\mathrm{kg} \text { MNTX }\end{array}$ & i.v. & $\begin{array}{l}\text { Attenuation in delayed } \\
\text { gastric emptying }\end{array}$ & [157] \\
\hline $\begin{array}{l}\text { DB, R, } \\
\text { P-C }\end{array}$ & 14 & & $\begin{array}{l}0.05 \mathrm{mg} / \mathrm{kg} \text { morphine } \\
\text { i.v., } 19.2 \mathrm{mg} / \mathrm{kg} \\
\text { MNTX }\end{array}$ & p.o. & $\begin{array}{l}\text { Prevention and treatment of } \\
\text { OIC }\end{array}$ & [158] \\
\hline $\begin{array}{l}\text { DB, R, } \\
\text { P-C }\end{array}$ & 137 & $\begin{array}{l}\text { Patients with nonmalignant pain, } \\
\text { chronic opioid administration }\end{array}$ & $12 \mathrm{mg}$, 4 weeks & s.c. & Relief in OIC after 2 doses & [159] \\
\hline $\begin{array}{l}\mathrm{DB}, \mathrm{R}, \\
\mathrm{P}-\mathrm{C} \\
\mathrm{PG}\end{array}$ & 469 & & 4 weeks & s.c. & $\begin{array}{l}\text { Improvement in } \\
\text { constipation symptoms } \\
\text { over } 1 \text { month }\end{array}$ & {$[160]$} \\
\hline $\mathrm{R}, \mathrm{P}-\mathrm{C}$ & 460 & & $\begin{array}{l}12 \mathrm{mg} \text { QD or QOD, } \\
4 \text { weeks }\end{array}$ & s.c. & Relief of OIC & {$[161]$} \\
\hline $\begin{array}{l}\text { DB, PG, } \\
\text { P-C }\end{array}$ & $\begin{array}{l}\mathrm{n} 1: 515 \\
\mathrm{n} 2: \\
533\end{array}$ & Patients after surgery & $\begin{array}{l}12 \mathrm{mg} \text { or } 24 \mathrm{mg} \text {, max. } \\
10 \text { days }\end{array}$ & i.v. & Safe and well-tolerated drug & {$[162]$} \\
\hline $\begin{array}{l}\mathrm{DB}, \mathrm{R}, \\
\mathrm{PG} \\
\mathrm{P}-\mathrm{C}\end{array}$ & 33 & & $12 \mathrm{mg}$ QD, 4-7 days & s.c. & $\begin{array}{l}\text { Safe and well-tolerated drug } \\
\text { in OIC treatment }\end{array}$ & {$[163]$} \\
\hline $\begin{array}{l}\text { DB, R, } \\
\text { P-C }\end{array}$ & 133 & $\begin{array}{l}\text { Patients with advanced illness } \\
\text { and OIC }\end{array}$ & $\begin{array}{l}0.15 \mathrm{mg} / \mathrm{kg}, \mathrm{QOD}, \\
2 \text { weeks }\end{array}$ & s.c. & $\begin{array}{l}\text { Improved constipation } \\
\text { distress }\end{array}$ & {$[164]$} \\
\hline $\begin{array}{l}\text { DB, R, } \\
\text { P-C }\end{array}$ & 154 & & $\begin{array}{l}0.15-0.30 \mathrm{mg} / \mathrm{kg} \\
4 \text { months }\end{array}$ & s.c. & Defecation after $30 \mathrm{~min}$. & {$[165]$} \\
\hline $\begin{array}{l}\text { DB, R, } \\
\text { P-C }\end{array}$ & 133 & & $0.15 \mathrm{mg} / \mathrm{kg}, 2$ weeks & s.c. & Defecation after $4 \mathrm{~h}$ & [124] \\
\hline $\begin{array}{l}\mathrm{DB}, \mathrm{R} \\
\mathrm{P}-\mathrm{C} \\
\mathrm{PG}\end{array}$ & 66 & & $1 / 3 / 5 \mathrm{mg} / \mathrm{kg}, 1-3$ weeks & s.c. & $\begin{array}{r}\text { Reversal of OIC at } \\
\text { dose }=\text { or }>5 \mathrm{mg}\end{array}$ & {$[166]$} \\
\hline DB & 82 & & $0.15 \mathrm{mg} / \mathrm{kg}, 1$ month & s.c. & Improvement in OIC & [167] \\
\hline $\begin{array}{l}\text { DB, R, } \\
\text { P-C }\end{array}$ & 22 & $\begin{array}{l}\text { Patients with methadone induced } \\
\text { constipation }\end{array}$ & $\begin{array}{l}0.015 / 0.05 / 0.1 / 0.2 \mathrm{mg} / \\
\mathrm{kg}, 2 \text { days }\end{array}$ & i.v. & $\begin{array}{l}\text { Reversal of slowing of oral } \\
\text { cecal-transit time }\end{array}$ & {$[168]$} \\
\hline $\begin{array}{l}\mathrm{DB}, \mathrm{R}, \\
\mathrm{PG}, \\
\mathrm{P}-\mathrm{C}\end{array}$ & $\begin{array}{l}\mathrm{n} 1: 154 \\
\mathrm{n} 2: 133\end{array}$ & OIC & $0.15 / 0.30 \mathrm{mg} / \mathrm{kg}$ & s.c. & Safe and well-tolerated drug & [169] \\
\hline
\end{tabular}

$D B$ double-blind, $R$ randomized, $P G$ parallel group, $P-C$ placebo-controlled, $Q D$ once daily, $B I D$ twice daily

two doses (12 or $24 \mathrm{mg}$ ) $90 \mathrm{~min}$ after surgery and every $6 \mathrm{~h}$ for $24 \mathrm{~h}$ or 10 days. The primary efficiency end point was assessed as time from surgery to first intestine movement, and according to length of hospitalization there were no differences between all groups. The adverse effects were similar to those observed in other studies, including abdominal pain, nausea or vomiting. The additional outcome of this study was that the dose of $24 \mathrm{mg}$ was safe and well-tolerated by patients.

Finally, in another study, a cohort of 469 patients was divided into three groups: placebo, MNTX every day and MNTX alternating with placebo for 4 weeks [160]. The improvement in constipation was noted for both groups subcutaneously treated with MNTX.

Recently, Garten et al. [170] reported that MNTX was administered to an infant with paralytic ileus. The neonate was 8 days after surgery and treated with fentanyl $(2 \mu \mathrm{g} /$ $\mathrm{kg} / \mathrm{h})$. The first i.v. administration of MNTX $(0.15 \mathrm{mg} / \mathrm{kg})$ resolved intestinal dismobility after $15 \mathrm{~min}$. The neonate received 5 doses of MNTX and the intestinal transit was improved without any adverse side effects.

Antanals. Three novel candidates for PAMORA-type drugs, designated antanal-1, antanal-2 and antanal-2A have recently been reported by our group [171]. The antanals 
were shown to exhibit selective antagonist activity at MOR in the GI tract in vivo and in vitro. The antanals did not across BBB after i.p. administration in mice and may thus become valuable drug templates for the design of future PAMORA-type therapeutics.

Irritable bowel syndrome

IBS involves a dysregulation of interactions between central and peripheral nervous system, so called brain-gut axis [172]. By many, IBS is linked to disturbances in gut microbiota [173]. This disorder is associated with abdominal discomfort or pain associated with changed bowel habits for at least 3 days per month in the previous 3 months, with the absence of another organic disease [174]. In USA, $5-10 \%$ of population suffer from IBS with prevalence between 20 and 39 years of age [175]. The prevalence of IBS is $10-20 \%$ worldwide [176]. IBS patients report numerous extragastrointestinal symptoms such as fibromyalgia, irritable urinary bladder, changes in libido and energy levels [172].

The several types of IBS can be mentioned, they are associated with changes in colorectal motility. Patients with IBS suffer from altered bowel habits, ranging from diarrhea, constipation, alternating diarrhea and constipation or normal bowel habits. Patients with a clinically prominent gastrocolonic reflex exert increased postprandial colonic contractions. Predominant constipation IBS (IBS-C) is characteristic for patients with increased colonic contractions. There is also diarrhea-predominant IBS (IBS-D), which involves patients with reduced colonic contractions and alternating or mixed IBS subtypes (IBS-A). [177].

The treatment of IBS is still symptomatic, without a well-defined first-line therapy. One of the drugs applied to treat IBS is trimebutine (Fig. 9), which is a weak MOR agonist, but its clinical efficiency is unclear. Recently, the effect of trimebutine molecule modified with $\mathrm{NO}_{2}$-arginine residue $\left(\mathrm{NO}_{2}\right.$-Arg-Trim) was investigated in a rodent model of IBS [178]. $\mathrm{NO}_{2}$-Arg-Trim displayed significantly more potent analgesic activity than trimebutine in healthy

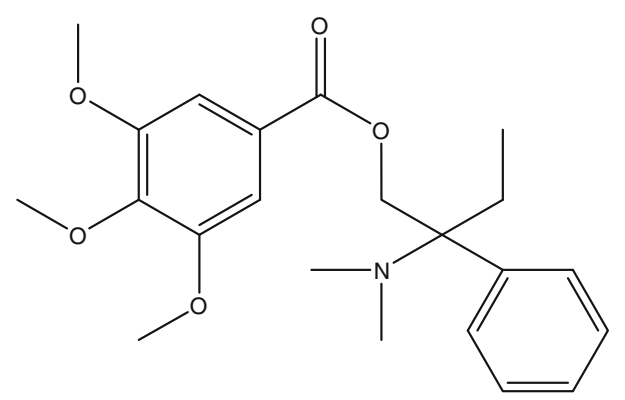

trimebutine

Fig. 9 Structure of trimebutine and post-colitis rats. The treatment with $\mathrm{NO}_{2}$-Arg-Trim also increased expression of genes involved in pain and inflammatory processes, including TNF- $\alpha$, IL- $1 \beta$, COX2 and iNOS, in tissue preparations from post-colitis rodents.

Linaclotide is a drug, which is useful in treatment of IBS and chronic constipation. Linaclotide is a peptide agonist of guanylate cyclase, which is important in active transport of $\mathrm{Cl}^{-}$into the intestinal lumen via CFTR channels. This drug causes increased stool water content and then relief in constipation [179]. The therapy for IBS was recently reviewed by Olden [180].

\section{Inflammatory bowel diseases}

Inflammatory bowel diseases (IBD) comprise two idiopathic ailments-Crohn's disease (CD) and ulcerative colitis (UC). It is estimated that $1-2 \%$ of the population has IBD and it is more common in women than men. It has been suggested that IBD involves a dysregulation of the immune response in the intestine evoked by commensal bacteria, and a genetic and an environmental predisposition was reported. The development of IBD may also imply a neural component, such as colonic nerve damage, changes in mucosal innervation and alterations in neuropeptide expression, e.g. SP, VIP and CRH [181]. The major therapeutic goals in IBD patients are the control of inflammation and the treatment of symptoms, which include abdominal pain and altered bowel movements [182].

Abdominal pain is a common symptom of IBD with a multifactorial etiology, described as a cramping sensation, varying in intensity and with exacerbations [179]. There are two types of abdominal pain-somatic, which is musculoskeletal and visceral-caused by stretching of the viscera and obstruction or widely affected inflammation. The development of visceral pain is associated with hypersensitivity of the primary sensory neurons in GI tract, which is subsequently has consequences in CNS. The changes in intrinsic sensory neurons properties and in gene expression regulation of nociceptive specific proteins lead to sensitization of primary afferent neurons. These changes contribute to increased production of pro-inflammatory molecules occurring via neurogenic inflammation, which are also involved in swelling, edema and vasodilation [183].

Since immune cells express opioid receptors, opioids may be involved in the regulation of inflammatory processes, with MOR ligands playing the most significant immunomodulatory role. Cabot et al. [184] showed that inflammation may increase the expression of POMC mRNA in immune cells, what results in elevated $\beta$ endorphin production and antinociceptive action. MOR agonists, DALDA and DAMGO, administered s.c., improved colitis in mice [182]. Furthermore, $\mathrm{MOR}^{-1-}$ mice were more prone to inflammation progress than wild 
type animals [182]. It was also demonstrated that opioids regulate the release of pro-inflammatory cytokines (e.g. IL-12, IL-6, TNF- $\alpha$ ) from peritoneal macrophages in mice [185]. The murine models of colitis proved that MOR exert anti-inflammatory effect on colon because of regulation of $\mathrm{T}$ cell proliferation and cytokine production [182]. The upregulation of MOR occurs during IBD with plausible beneficial effect on accelerated intestinal transit and duration of the inflammatory process.

It can be helpful in prevention overt pathological intestinal inflammation [186].

Goldsmith et al. [187] reported that the administration of the MOR agonist, DALDA protected against DSS-induced bowel injury in mice by promoting Stat3 phosphorylation in intestinal epithelial cells, which led to an increased expression of cytoprotective genes (Reg3b, Ccndl, Cox2, $m y c$ ), enterocyte proliferation and enhanced wound healing. DALDA may thus be useful in the treatment of diseases associated with intestinal barrier damage, e.g. IBD or radiation-induced damage.

Recent data suggest that blockade of MOR may also alleviate inflammation and, therefore, MOR antagonists have become an attractive target for drug design in the field of IBD. The anti-inflammatory action of the MOR antagonist, naltrexone in the mouse model of DSS-induced colitis was first described by Matters et al. [188]. Administration of naltrexone decreased the over-expression of pro-inflammatory cytokines IL- 6 and IL-12 and improved mucosal structure. Jan et al. [189] showed that the administration of naloxone significantly inhibited endotoxin-induced activation of $\mathrm{NF}-\kappa \mathrm{B}$ in RAW264.7 cell culture, which is a major intracellular pathway involved in the expression of pro-inflammatory molecules. The proposed explanation of naloxone on NF- $\mathrm{KB}$ was mediated mainly by L-type calcium channels than opioid receptors. Interestingly, the administration of morphine enhanced the effect of naloxone as an anti-inflammatory compound.

To the best of our knowledge, there is only one clinical trial using opioids as an anti-inflammatory drug. In the randomized double-blind placebo controlled study, adult patients were treated with naltrexone $(4.5 \mathrm{mg})$ or placebo for 12 weeks [190]. Colonoscopies were performed for all patients before and after the study and the results were reported according to the $\mathrm{CD}$ activity index (CDAI) scoring system. A significant improvement in GI mucosal inflammation was observed in patients after naltrexone therapy. The side effects of naltrexone treatment included insomnia, diarrhea and abdominal pain.

\section{Sepsis}

Bacterial sepsis, which is quite common in patients after surgical intervention in comparison with controls without surgery, is an important and unsolved problem in medicine, which affects, among others, the function of the GI tract.

It seems likely that opioid receptors may be involved in the development of sepsis and that morphine and other opioids may act as cofactors in its precipitation. Hilburger et al. [191] observed that morphine administration in slowrelease pellets in mice caused the escape of Gram-negative and enteric bacteria (e.g. Proteus mirabilis, Escherichia coli, Enterococcus faecalis) from GI tract to the liver, the spleen and peritoneum, and led to septic state. Moreover, the application of naltrexone blocked the effect of morphine, indicating that opioid receptors are involved in sepsis development.

The cecal ligation and perforation (CLP) is used as an animal model of bacterial peritonitis, comparable with human sepsis. Topcu et al. [192] showed that the administration of fentanyl caused significant antitransit effects in the presence of systemic inflammation in rats. Furthermore, a higher antitransit effect of fentanyl was observed in rats with CLP than in the sham group. It was suggested that the peritoneal inflammation evokes sensitization of opioid receptors located in the myenteric and the submucosal plexuses in peripheral or central nerve terminals and increased the effects induced by administration of exogenous opioids, in particular MOR and DOR-selective. This is in good agreement with the study by Nardi et al. [193], who showed that opioid receptor agonists fentanyl and tramadol alleviated pain in rat CLP model. However, adverse side effects occurring after their administration, such as alteration of cardiovascular parameters and high mortality, did not allow for their chronic use.

Opioid receptors are a possible pharmacological target for the treatment of sepsis. Tang et al. [194], using rat CLP model, showed that DADLE $(5 \mathrm{mg} / \mathrm{kg}$, i.p. $)$, a synthetic analog of $\left[\mathrm{Leu}^{5}\right]$ enkephalin, protected against lethal endotoxemia in a DOR-dependent manner. In addition, concurrent and delayed treatment of rats with DADLE $\left(10^{-6} \mathrm{M}\right)$ suppressed LPS-induced apoptosis and necrosis. DADLE inhibited signal transduction in macrophages after LPS stimulation via modulation of MAPK and NFKB pathways and decreased concentration of TNF- $\alpha$, IFN- $\gamma$, Il- $1 \beta$ in serum. The most important observation from the clinical point of view was that DADLE inhibited the release of HMBG1, a late pro-inflammatory cytokine which binds to DNA and is responsible for stimulation of genes involved in inflammatory response, from macrophages even $4 \mathrm{~h}$ after the onset of inflammation. This observation may encourage novel treatment strategies of sepsis.

\section{Conclusion and future perspectives}

The most anticipated goal of contemporary drug discovery is the development of a personalized therapy, which 
requires good knowledge of the treated disease at a molecular and genetic level and involves a careful selection of drugs, depending on the molecular target in the cells. The opioid receptor-based personalized therapy would primarily aim at the inhibition of molecular pathways responsible for the adverse side effects of opioid ligands, such as development of tolerance or OBD. Consequently, opioid peptide gene therapy was extensively studied in the last few years. The delivery of genes or their fragments encoding enkephalins, $\beta$-endorphin or EMs was already validated in numerous animal models $[195,196]$.

Conventional treatment of many GI disorders and malfunctions is limited to pure overcoming of their symptoms and associated with adverse side effects of drugs used. For example, currently available treatment for the intestinal inflammation, based on 5-aminosalicylate, corticosteroids and immunomodulators involves attenuation of inflammatory reaction and plain maintenance of this condition. Peripherally restricted opioids, which would act directly and indirectly on immune cells, might become important tools in the modulation of the immune system response and alleviation of the inflammatory state.

Other novel diagnostic and treatment strategies for GI disorders, implied by the presence of opioid receptors and their ligands in the GI tract and their crucial role in GI physiology and pathophysiology, are currently under investigation.

Acknowledgments Supported by the Iuventus Plus program of the Polish Ministry of Science and Higher Education (0119/IP1/2011/71 to JF) and the National Natural Science Foundation of China (NSFC) Research Fund for International Young Scientists (81250110087 to $\mathrm{JF})$.

Conflict of interest The authors declare that they have no conflict of interest.

Open Access This article is distributed under the terms of the Creative Commons Attribution Noncommercial License which permits any noncommercial use, distribution, and reproduction in any medium, provided the original author(s) and the source are credited.

\section{References}

1. Pert CB, Snyder SH. Opiate receptor: demonstration in nervous tissue. Science. 1973;179:1011-4.

2. Lord JA, Waterfield AA, Hughes J, Kosterlitz HW. Endogenous opioid peptides: multiple agonists and receptors. Nature. 1977;267:495-9.

3. Dupre DJ, Robitaille M, Rebois RV, Hebert TE. The role of Gbetagamma subunits in the organization, assembly, and function of GPCR signaling complexes. Annu Rev Pharmacol Toxicol. 2009;49:31-56.

4. Piros ET, Hales TG, Evans CJ. Functional analysis of cloned opioid receptors in transfected cell lines. Neurochem Res. 1996;21:1277-85.
5. Evans CJ, Keith DE Jr, Morrison H, Magendzo K, Edwards RH. Cloning of a delta opioid receptor by functional expression. Science. 1992;258:1952-5.

6. Li S, Zhu J, Chen C, Chen YW, Deriel JK, Ashby B, et al. Molecular cloning and expression of a rat kappa opioid receptor. Biochem J. 1993;295:629-33.

7. Chen Y, Mestek A, Liu J, Yu L. Molecular cloning of a rat kappa opioid receptor reveals sequence similarities to the mu and delta opioid receptors. Biochem J. 1993;295:625-8.

8. Fukuda K, Kato S, Mori K, Nishi M, Takeshima H. Primary structures and expression from cDNAs of rat opioid receptor delta- and mu-subtypes. FEBS Lett. 1993;327:311-4.

9. Dietis N, Rowbotham DJ, Lambert DG. Opioid receptor subtypes: fact or artifact? Br J Anaesth. 2011;107:8-18.

10. Zollner C, Stein C. Opioids. Handb Exp Pharmacol. 2007;177: 31-63.

11. Jordan BA, Cvejic S, Devi LA. Opioids and their complicated receptor complexes. Neuropsychopharmacology. 2000;23:S5-18.

12. Chaturvedi K, Christoffers KH, Singh K, Howells RD. Structure and regulation of opioid receptors. Biopolymers. 2000;55:334-46.

13. Befort K, Tabbara L, Bausch S, Chavkin C, Evans C, Kieffer B. The conserved aspartate residue in the third putative transmembrane domain of the delta-opioid receptor is not the anionic counterpart for cationic opiate binding but is a constituent of the receptor binding site. Mol Pharmacol. 1996;49:216-23.

14. Surratt CK, Johnson PS, Moriwaki A, Seidleck BK, Blaschak $\mathrm{CJ}$, Wang JB, et al. mu opiate receptor. Charged transmembrane domain amino acids are critical for agonist recognition and intrinsic activity. J Biol Chem. 1994;269:20548-53.

15. Chan AS, Law PY, Loh HH, Ho PN, Wu WM, Chan JS, et al. The first and third intracellular loops together with the carboxy terminal tail of the delta-opioid receptor contribute toward functional interaction with Galpha16. J Neurochem. 2003;87: $697-708$.

16. Reisine T, Law SF, Blake A, Tallent M. Molecular mechanisms of opiate receptor coupling to $\mathrm{G}$ proteins and effector systems. Ann N Y Acad Sci. 1996;780:168-75.

17. Clark MJ, Neubig RR, Traynor JR. Endogenous regulator of $\mathrm{G}$ protein signaling proteins suppress Galphao-dependent, mu-opioid agonist-mediated adenylyl cyclase supersensitization. J Pharmacol Exp Ther. 2004;310:215-22.

18. Law PY, Wong YH, Loh HH. Molecular mechanisms and regulation of opioid receptor signaling. Annu Rev Pharmacol Toxicol. 2000;40:389-430.

19. Piros ET, Prather PL, Law PY, Evans CJ, Hales TG. Voltagedependent inhibition of $\mathrm{Ca}^{2+}$ channels in $\mathrm{GH} 3$ cells by cloned mu- and delta-opioid receptors. Mol Pharmacol. 1996;50:947-56.

20. Georgoussi Z, Georganta EM, Milligan G. The other side of opioid receptor signalling: regulation by protein-protein interaction. Curr Drug Targets. 2012;13:80-102.

21. Lefkowitz RJ, Shenoy SK. Transduction of receptor signals by beta-arrestins. Science. 2005;308:512-7.

22. Maguma H, Thayne K, Taylor DA. Characteristics of tolerance in the guinea pig ileum produced by chronic in vivo exposure to opioid versus cannabinoid agonists. Biochem Pharmacol. 2010;80:522-32.

23. Bohn LM, Gainetdinov RR, Lin FT, Lefkowitz RJ, Caron MG. $\mathrm{Mu}$-opioid receptor desensitization by beta-arrestin-2 determines morphine tolerance but not dependence. Nature. 2000; 408:720-3.

24. Fernandez Robles CR, Degnan M, Candiotti KA. Pain and genetics. Curr Opin Anaesthesiol. 2012;25:444-9.

25. Levran O, Yuferov V, Kreek MJ. The genetics of the opioid system and specific drug addictions. Hum Genet. 2012;131: $823-42$. 
26. Raynor K, Kong H, Mestek A, Bye LS, Tian M, Liu J, et al. Characterization of the cloned human mu opioid receptor. J Pharmacol Exp Ther. 1995;272:423-8.

27. Chadzinska M. Opioid system and innate immunity. Comparative studies. I. Opioids and opioid receptors. Adv Cell Biol. 2007;34:251-62.

28. Cruz-Gordillo P, Fedrigo O, Wray GA, Babbitt CC. Extensive changes in the expression of the opioid genes between humans and chimpanzees. Brain Behav Evol. 2010;76:154-62.

29. Sehgal N, Smith HS, Manchikanti L. Peripherally acting opioids and clinical implications for pain control. Pain Physician. 2011; $14: 249-58$.

30. Zhang H, Luo X, Kranzler HR, Lappalainen J, Yang BZ, Krupitsky E, et al. Association between two mu-opioid receptor gene (OPRM1) haplotype blocks and drug or alcohol dependence. Hum Mol Genet. 2006;15:807-19.

31. Finco G, Pintor M, Sanna D, Orru G, Musu M, De CF, et al. Is target opioid therapy within sight? Minerva Anestesiol. 2012;78: 462-72.

32. Kosarac B, Fox AA, Collard CD. Effect of genetic factors on opioid action. Curr Opin Anaesthesiol. 2009;22:476-82.

33. Chavkin C, McLaughlin JP, Celver JP. Regulation of opioid receptor function by chronic agonist exposure: constitutive activity and desensitization. Mol Pharmacol. 2001;60:20-5.

34. Klepstad P, Rakvag TT, Kaasa S, Holthe M, Dale O, Borchgrevink PC, et al. The $118 \mathrm{~A}>\mathrm{G}$ polymorphism in the human mu-opioid receptor gene may increase morphine requirements in patients with pain caused by malignant disease. Acta Anaesthesiol Scand. 2004;48:1232-9.

35. Walter C, Lotsch J. Meta-analysis of the relevance of the OPRM1 118A $>$ G genetic variant for pain treatment. Pain. 2009;146:270-5.

36. Ashenhurst JR, Bujarski S, Ray LA. Delta and kappa opioid receptor polymorphisms influence the effects of naltrexone on subjective responses to alcohol. Pharmacol Biochem Behav. 2012;103:253-9.

37. Crist RC, Ambrose-Lanci LM, Vaswani M, Clarke TK, Zeng A, Yuan $\mathrm{C}$, et al. Case-control association analysis of polymorphisms in the delta-opioid receptor, OPRD1, with cocaine and opioid addicted populations. Drug Alcohol Depend. 2013;127: 122-8.

38. Arias AJ, Armeli S, Gelernter J, Covault J, Kallio A, Karhuvaara $\mathrm{S}$, et al. Effects of opioid receptor gene variation on targeted nalmefene treatment in heavy drinkers. Alcohol Clin Exp Res. 2008;32:1159-66.

39. Zhang H, Gelernter J, Gruen JR, Kranzler HR, Herman AI, Simen AA. Functional impact of a single-nucleotide polymorphism in the OPRD1 promoter region. J Hum Genet. 2010;55:278-84.

40. Gelernter J, Kranzler HR. Genetics of drug dependence. Dialogues Clin Neurosci. 2010;12:77-84.

41. Edenberg HJ, Wang J, Tian H, Pochareddy S, Xuei X, Wetherill $\mathrm{L}$, et al. A regulatory variation in OPRK1, the gene encoding the kappa-opioid receptor, is associated with alcohol dependence. Hum Mol Genet. 2008;17:1783-9.

42. Peng J, Sarkar S, Chang SL. Opioid receptor expression in human brain and peripheral tissues using absolute quantitative real-time RT-PCR. Drug Alcohol Depend. 2012;124:223-8.

43. Holzer P. Opioid antagonists for prevention and treatment of opioid-induced gastrointestinal effects. Curr Opin Anaesthesiol. 2010;23:616-22.

44. Wood JD, Galligan JJ. Function of opioids in the enteric nervous system. Neurogastroenterol Motil. 2004;16(Suppl 2):17-28.

45. Sternini C, Patierno S, Selmer IS, Kirchgessner A. The opioid system in the gastrointestinal tract. Neurogastroenterol Motil. 2004;16(Suppl 2):3-16.
46. DeHaven-Hudkins DL, DeHaven RN, Little PJ, Techner LM. The involvement of the mu-opioid receptor in gastrointestinal pathophysiology: therapeutic opportunities for antagonism at this receptor. Pharmacol Ther. 2008;117:162-87.

47. Poole DP, Pelayo JC, Scherrer G, Evans CJ, Kieffer BL, Bunnett NW. Localization and regulation of fluorescently labeled delta opioid receptor, expressed in enteric neurons of mice. Gastroenterology. 2011;141:982-91.

48. Phan NQ, Lotts T, Antal A, Bernhard JD, Stander S. Systemic kappa opioid receptor agonists in the treatment of chronic pruritus: a literature review. Acta Derm Venereol. 2012;92:555-60.

49. Bagnol D, Mansour A, Akil H, Watson SJ. Cellular localization and distribution of the cloned mu and kappa opioid receptors in rat gastrointestinal tract. Neuroscience. 1997;81:579-91.

50. Kurz A, Sessler DI. Opioid-induced bowel dysfunction: pathophysiology and potential new therapies. Drugs. 2003;63:649-71.

51. Holzer P. Opioids and opioid receptors in the enteric nervous system: from a problem in opioid analgesia to a possible new prokinetic therapy in humans. Neurosci Lett. 2004;361:192-5.

52. Donnerer J, Liebmann I. Stimulus-evoked opioid inhibition in guinea-pig longitudinal muscle-myenteric plexus strip is modulated by NMDA receptors. Neurosci Lett. 2007;419:74-7.

53. Patierno S, Zellalem W, Ho A, Parsons CG, Lloyd KC, Tonini $\mathrm{M}$, et al. N-methyl-D-aspartate receptors mediate endogenous opioid release in enteric neurons after abdominal surgery. Gastroenterology. 2005;128:2009-19.

54. Donnerer J, Liebmann I. Evidence for opioid-induced release of glutamate in guinea pig longitudinal muscle-myenteric plexus strip. Neurosci Lett. 2009;462:118-20.

55. Iwata H, Tsuchiya S, Nakamura T, Yano S. Morphine leads to contraction of the ileal circular muscle via inhibition of the nitrergic pathway in mice. Eur J Pharmacol. 2007;574:66-70.

56. De LA, Coupar IM. Insights into opioid action in the intestinal tract. Pharmacol Ther. 1996;69(2):103-15.

57. Brock C, Olesen SS, Olesen AE, Frokjaer JB, Andresen T, Drewes AM. Opioid-induced bowel dysfunction: pathophysiology and management. Drugs. 2012;72:1847-65.

58. Barrett KE. New insights into the pathogenesis of intestinal dysfunction: secretory diarrhea and cystic fibrosis. World $\mathrm{J}$ Gastroenterol. 2000;6:470-4.

59. Barrett KE, Keely SJ. Chloride secretion by the intestinal epithelium: molecular basis and regulatory aspects. Annu Rev Physiol. 2000;62:535-72.

60. Herman MA, Gillis RA, Vicini S, Dretchen KL, Sahibzada N. Tonic GABAA receptor conductance in medial subnucleus of the tractus solitarius neurons is inhibited by activation of muopioid receptors. J Neurophysiol. 2012;107:1022-31.

61. Herman MA, Alayan A, Sahibzada N, Bayer B, Verbalis J, Dretchen KL, et al. micro-Opioid receptor stimulation in the medial subnucleus of the tractus solitarius inhibits gastric tone and motility by reducing local GABA activity. Am J Physiol Gastrointest Liver Physiol. 2010;299:G494-506.

62. Vilardaga JP, Bunemann M, Feinstein TN, Lambert N, Nikolaev VO, Engelhardt S, et al. GPCR and G proteins: drug efficacy and activation in live cells. Mol Endocrinol. 2009;23:590-9.

63. Gomez MP, Nasi E. Light transduction in invertebrate hyperpolarizing photoreceptors: possible involvement of a Go-regulated guanylate cyclase. J Neurosci. 2000;20:5254-63.

64. Law PY, Erickson-Herbrandson LJ, Zha QQ, Solberg J, Chu J, Sarre A, et al. Heterodimerization of mu- and delta-opioid receptors occurs at the cell surface only and requires receptor-G protein interactions. J Biol Chem. 2000;280:11152-64.

65. Berger AC, Whistler JL. Morphine-induced mu opioid receptor trafficking enhances reward yet prevents compulsive drug use. EMBO Mol Med. 2011;3:385-97. 
66. Milligan G. G protein-coupled receptor dimerisation: molecular basis and relevance to function. Biochim Biophys Acta. 2007; 1768:825-35.

67. Milligan G, Parenty G, Stoddart LA, Lane JR. Novel pharmacological applications of G-protein-coupled receptor-G protein fusions. Curr Opin Pharmacol. 2007;7:521-6.

68. Al-Hasani R, Bruchas MR. Molecular mechanisms of opioid receptor-dependent signaling and behavior. Anesthesiology. 2011;115:1363-81.

69. Rios C, Gomes I, Devi LA. mu opioid and CB1 cannabinoid receptor interactions: reciprocal inhibition of receptor signaling and neuritogenesis. Br J Pharmacol. 2006;148:387-95.

70. Holzer P. Opioid receptors in the gastrointestinal tract. Regul Pept. 2009;155:11-7.

71. Bunchorntavakul C, Reddy KR. Pruritus in chronic cholestatic liver disease. Clin Liver Dis. 2012;16:331-46.

72. Headrick JP, Pepe S, Peart JN. Non-analgesic effects of opioids: cardiovascular effects of opioids and their receptor systems. Curr Pharm Des. 2012;18:6090-100.

73. Husain S, Abdul Y, Potter DE. Non-Analgesic Effects of Opioids: neuroprotection in the Retina. Curr Pharm Des. 2012;18:6101-8.

74. Kromer W. Endogenous and exogenous opioids in the control of gastrointestinal motility and secretion. Pharmacol Rev. 1988; 40:121-62.

75. Panchal SJ, Muller-Schwefe P, Wurzelmann JI. Opioid-induced bowel dysfunction: prevalence, pathophysiology and burden. Int J Clin Pract. 2007;61:1181-7.

76. Collins S, Verma-Gandhu M. The putative role of endogenous and exogenous opiates in inflammatory bowel disease. Gut. 2006;55:756-7.

77. Owczarek D, Cibor D, Mach T, Ciesla A, Pierzchala-Koziec K, Salapa K, et al. Met-enkephalins in patients with inflammatory bowel diseases. Adv Med Sci. 2011;56:158-64.

78. Al-Khrasani M, Lacko E, Riba P, Kiraly K, Sobor M, Timar J, et al. The central versus peripheral antinociceptive effects of mu-opioid receptor agonists in the new model of rat visceral pain. Brain Res Bull. 2012;87:238-43.

79. Xu GY, Winston JH, Chen JD. Electroacupuncture attenuates visceral hyperalgesia and inhibits the enhanced excitability of colon specific sensory neurons in a rat model of irritable bowel syndrome. Neurogastroenterol Motil. 2009;21:1302-e125.

80. Zadina JE, Hackler L, Ge LJ, Kastin AJ. A potent and selective endogenous agonist for the mu-opiate receptor. Nature. 1997;386: 499-502.

81. Storr M, Geisler F, Neuhuber WL, Schusdziarra V, Allescher HD. Endomorphin-1 and -2, endogenous ligands for the mu-opioid receptor, inhibit striated and smooth muscle contraction in the rat oesophagus. Neurogastroenterol Motil. 2000;12:441-8.

82. Nishiwaki H, Saitoh N, Nishio H, Takeuchi T, Hata F. Relationship between muscarinic autoinhibition and the inhibitory effect of morphine on acetylcholine release from myenteric plexus of guinea pig ileum. Jpn J Pharmacol. 1998;77:271-8.

83. Nishiwaki H, Saitoh N, Nishio H, Takeuchi T, Hata F. Inhibitory effect of endomorphin-1 and -2 on acetylcholine release from myenteric plexus of guinea pig ileum. Jpn J Pharmacol. 1998; 78:83-6.

84. Yu Y, Cui Y, Wang X, Lai LH, Wang CL, Fan YZ, et al. In vitro characterization of the effects of endomorphin 1 and 2, endogenous ligands for mu-opioid receptors, on mouse colonic motility. Biochem Pharmacol. 2007;73:1384-93.

85. Azuma Y, Ohura K. Endomorphin-2 modulates productions of TNF-alpha, IL-1beta, IL-10, and IL-12, and alters functions related to innate immune of macrophages. Inflammation. 2002; 26:223-32.
86. Janecka A, Perlikowska R, Gach K, Wyrebska A, Fichna J. Development of opioid peptide analogs for pain relief. Curr Pharm Des. 2010;16:1126-35.

87. Varamini P, Mansfeld FM, Blanchfield JT, Wyse BD, Smith MT, Toth I. Synthesis and biological evaluation of an orally active glycosylated endomorphin-1. J Med Chem. 2012;55:5859-67.

88. Kaneko K, Iwasaki M, Yoshikawa M, Ohinata K. Orally administered soymorphins, soy-derived opioid peptides, suppress feeding and intestinal transit via gut mu(1)-receptor coupled to 5-HT(1A), D(2), and GABA(B) systems. Am J Physiol Gastrointest Liver Physiol. 2010;299:G799-805.

89. Chiba H, Tani F, Yoshikawa M. Opioid antagonist peptides derived from kappa-casein. J Dairy Res. 1989;56:363-6.

90. Patten GS, Head RJ, Abeywardena MY. Effects of casoxin 4 on morphine inhibition of small animal intestinal contractility and gut transit in the mouse. Clin Exp Gastroenterol. 2011;4:23-31.

91. Stefano GB, Ptacek R, Kuzelova H, Kream RM. Endogenous morphine: up-to-date review 2011. Folia Biol. 2012;58:49-56.

92. Netzer P, Sendensky A, Wissmeyer MP, Baumeler S, Batista C, Scheurer $\mathrm{U}$, et al. The effect of naloxone-3-glucuronide on colonic transit time in healthy men after acute morphine administration: a placebo-controlled double-blinded crossover preclinical volunteer study. Aliment Pharmacol Ther. 2008;28:1334-41.

93. Reber P, Brenneisen R, Flogerzi B, Batista C, Netzer P, Scheurer $\mathrm{U}$. Effect of naloxone-3-glucuronide and $\mathrm{N}$-methylnaloxone on the motility of the isolated rat colon after morphine. Dig Dis Sci. 2007;52:502-7.

94. Ross GR, Gabra BH, Dewey WL, Akbarali HI. Morphine tolerance in the mouse ileum and colon. J Pharmacol Exp Ther. 2008;327:561-72.

95. Aquilante CL, Letrent SP, Pollack GM, Brouwer KL. Increased brain P-glycoprotein in morphine tolerant rats. Life Sci. 2000; 66:L47-51.

96. King M, Su W, Chang A, Zuckerman A, Pasternak GW. Transport of opioids from the brain to the periphery by P-glycoprotein: peripheral actions of central drugs. Nat Neurosci. 2001;4:268-74.

97. Yousif S, Saubamea B, Cisternino S, Marie-Claire C, Dauchy S, Scherrmann JM, et al. Effect of chronic exposure to morphine on the rat blood-brain barrier: focus on the P-glycoprotein. J Neurochem. 2008;107:647-57.

98. Anastassopoulos KP, Chow W, Tapia CI, Baik R, Ackerman SJ, Biondi D, et al. Economic study on the impact of side effects in patients taking oxycodone controlled-release for noncancer pain. J Manag Care Pharm. 2012;18:615-26.

99. Peng X, Cebra JJ, Adler MW, Meissler JJ Jr, Cowan A, Feng P, et al. Morphine inhibits mucosal antibody responses and TGFbeta mRNA in gut-associated lymphoid tissue following oral cholera toxin in mice. J Immunol. 2001;167:3677-81.

100. Breslow JM, Feng P, Meissler JJ, Pintar JE, Gaughan J, Adler MW, et al. Potentiating effect of morphine on oral Salmonella enterica serovar Typhimurium infection is mu-opioid receptordependent. Microb Pathog. 2010;49:330-5.

101. Feng P, Rahim RT, Cowan A, Liu-Chen LY, Peng X, Gaughan J, et al. Effects of mu, kappa or delta opioids administered by pellet or pump on oral Salmonella infection and gastrointestinal transit. Eur J Pharmacol. 2006;534:250-7.

102. Babrowski T, Holbrook C, Moss J, Gottlieb L, Valuckaite V, Zaborin A, et al. Pseudomonas aeruginosa virulence expression is directly activated by morphine and is capable of causing lethal gut-derived sepsis in mice during chronic morphine administration. Ann Surg. 2012;255:386-93.

103. Glattard E, Welters ID, Lavaux T, Muller AH, Laux A, Zhang D, et al. Endogenous morphine levels are increased in sepsis: a partial implication of neutrophils. PLoS ONE. 2010;5:e8791. 
104. Capasso R, Borrelli F, Capasso F, Siebert DJ, Stewart DJ, Zjawiony JK, et al. The hallucinogenic herb Salvia divinorum and its active ingredient salvinorin A inhibit enteric cholinergic transmission in the guinea-pig ileum. Neurogastroenterol Motil. 2006;18:69-75.

105. Fichna J, Schicho R, Andrews CN, Bashashati M, Klompus M, McKay DM, et al. Salvinorin A inhibits colonic transit and neurogenic ion transport in mice by activating kappa-opioid and cannabinoid receptors. Neurogastroenterol Motil. 2009;21:1326e128.

106. Capasso R, Borrelli F, Cascio MG, Aviello G, Huben K, Zjawiony JK, et al. Inhibitory effect of salvinorin A, from Salvia divinorum, on ileitis-induced hypermotility: cross-talk between kappa-opioid and cannabinoid CB(1) receptors. Br J Pharmacol. 2008;155:681-9.

107. Fichna J, Dicay M, Hirota SA, Traboulsi D, Macdonald JA, Janecka A, et al. Differential effects of salvinorin A on endotoxin-induced hypermotility and neurogenic ion transport in mouse ileum. Neurogastroenterol Motil. 2011;23:583-e212.

108. Fichna J, Dicay M, Lewellyn K, Janecka A, Zjawiony JK, MacNaughton WK, et al. Salvinorin A has antiinflammatory and antinociceptive effects in experimental models of colitis in mice mediated by KOR and CB1 receptors. Inflamm Bowel Dis. 2012;18:1137-45.

109. Fichna J, Schicho R, Janecka A, Zjawiony JK, Storr M. Selective natural kappa opioid and cannabinoid receptor agonists with a potential role in the treatment of gastrointestinal dysfunction. Drug News Perspect. 2009;22:383-92.

110. Laugsand EA, Kaasa S, Klepstad P. Management of opioidinduced nausea and vomiting in cancer patients: systematic review and evidence-based recommendations. Palliat Med. 2011;25:442-53.

111. Chen W, Chung HH, Cheng JT. Opiate-induced constipation related to activation of small intestine opioid mu2-receptors. World J Gastroenterol. 2012;18:1391-6.

112. Kumar R, Reeta KH, Ray SB. Antinociceptive effect of intrathecal loperamide: role of mu-opioid receptor and calcium channels. Eur J Pharmacol. 2012;696:77-82.

113. Primi MP, Bueno L, Baumer P, Berard H, Lecomte JM. Racecadotril demonstrates intestinal antisecretory activity in vivo. Aliment Pharmacol Ther. 1999;13:3-7.

114. Duncker SC, Philippe D, Martin-Paschoud C, Moser M, Mercenier A, Nutten S. Nigella sativa (Black Cumin) seed extract alleviates symptoms of allergic diarrhea in mice, involving opioid receptors. PLoS One. 2012;7:e39841.

115. Isik F, Tunali AT, Yarat A, Genc Z, Pisiriciler R, Caliskan-Ak E, et al. Protective effects of black cumin (Nigella sativa) oil on TNBS-induced experimental colitis in rats. Dig Dis Sci. 2011;56:721-30.

116. Boskabady MH, Mohsenpoor N, Takaloo L. Antiasthmatic effect of Nigella sativa in airways of asthmatic patients. Phytomedicine. 2010;17:707-13.

117. Banerjee S, Padhye S, Azmi A, Wang Z, Philip PA, Kucuk O, et al. Review on molecular and therapeutic potential of thymoquinone in cancer. Nutr Cancer. 2010;62:938-46.

118. Hirata T, Keto Y, Nakata M, Takeuchi A, Funatsu T, Akuzawa $\mathrm{S}$, et al. Effects of serotonin 5-HT3 receptor antagonists on stress-induced colonic hyperalgesia and diarrhoea in rats: a comparative study with opioid receptor agonists, a muscarinic receptor antagonist and a synthetic polymer. Neurogastroenterol Motil. 2008;20:557-65.

119. McNicol E, Horowicz-Mehler N, Fisk RA, Bennett K, GialeliGoudas M, Chew PW, et al. Management of opioid side effects in cancer-related and chronic noncancer pain: a systematic review. J Pain. 2003;4:231-56.
120. Gwee KA. Irritable bowel syndrome in developing countries-a disorder of civilization or colonization? Neurogastroenterol Motil. 2005;17:317-24.

121. Pappagallo M. Incidence, prevalence, and management of opioid bowel dysfunction. Am J Surg. 2001;182:11S-8S

122. Deibert P, Xander C, Blum HE, Becker G. Methylnaltrexone: the evidence for its use in the management of opioid-induced constipation. Core Evid. 2010;4:247-58.

123. Leppert W. The role of opioid receptor antagonists in the treatment of opioid-induced constipation: a review. Adv Ther. 2010;27:714-30.

124. Thomas J, Karver S, Cooney GA, Chamberlain BH, Watt CK, Slatkin NE, et al. Methylnaltrexone for opioid-induced constipation in advanced illness. N Engl J Med. 2008;358:2332-43.

125. Jakab RL, Collaco AM, Ameen NA. Lubiprostone targets prostanoid signaling and promotes ion transporter trafficking, mucus exocytosis, and contractility. Dig Dis Sci. 2012;57:2826-45.

126. Norimatsu Y, Moran AR, Macdonald KD. Lubiprostone activates CFTR, but not $\mathrm{ClC}-2$, via the prostaglandin receptor (EP(4)). Biochem Biophys Res Commun. 2012;426:374-9.

127. Ao M, Venkatasubramanian J, Boonkaewwan C, Ganesan N, Syed A, Benya RV, et al. Lubiprostone activates Cl- secretion via cAMP signaling and increases membrane CFTR in the human colon carcinoma cell line, T84. Dig Dis Sci. 2011;56:339-51.

128. Sun X, Wang X, Wang GD, Xia Y, Liu S, Qu M, et al. Lubiprostone reverses the inhibitory action of morphine on mucosal secretion in human small intestine. Dig Dis Sci. 2011;56:330-8.

129. Fei G, Raehal K, Liu S, Qu MH, Sun X, Wang GD, et al. Lubiprostone reverses the inhibitory action of morphine on intestinal secretion in guinea pig and mouse. J Pharmacol Exp Ther. 2010;334:333-40.

130. Chamberlain SM, Rao SS. Safety evaluation of lubiprostone in the treatment of constipation and irritable bowel syndrome. Expert Opin Drug Saf. 2012;11:841-50.

131. Kalff JC, Schraut WH, Billiar TR, Simmons RL, Bauer AJ. Role of inducible nitric oxide synthase in postoperative intestinal smooth muscle dysfunction in rodents. Gastroenterology. 2000;118:316-27.

132. Bauer AJ, Boeckxstaens GE. Mechanisms of postoperative ileus. Neurogastroenterol Motil. 2004;16:54-60.

133. Beard TL, Leslie JB, Nemeth J. The opioid component of delayed gastrointestinal recovery after bowel resection. J Gastrointest Surg. 2011;15:1259-68.

134. Thompson M, Magnuson B. Management of postoperative ileus. Orthopedics. 2012;35:213-7.

135. Pfab F, Nowak-Machen M, Napadow V, Fleckenstein J. Alternatives to prokinetics to move the pylorus and colon. Curr Opin Clin Nutr Metab Care. 2012;15:166-73.

136. Schmidt J, Stoffels B, Nazir A. haven-Hudkins DL, Bauer AJ. Alvimopan and COX-2 inhibition reverse opioid and inflammatory components of postoperative ileus. Neurogastroenterol Motil. 2008;20:689-99.

137. Delaney CP, Weese JL, Hyman NH, Bauer J, Techner L, Gabriel $\mathrm{K}$, et al. Phase III trial of alvimopan, a novel, peripherally acting, mu opioid antagonist, for postoperative ileus after major abdominal surgery. Dis Colon Rectum. 2005;48:1114-25.

138. Apfel CC, Jalota L. Can central antiemetic effects of opioids counter-balance opioid-induced nausea and vomiting? Acta Anaesthesiol Scand. 2010;54:129-31.

139. Marderstein EL, Delaney CP. Management of postoperative ileus: focus on alvimopan. Ther Clin Risk Manag. 2008;4:965-73.

140. Webster L, Jansen JP, Peppin J, Lasko B, Irving G, Morlion B, et al. Alvimopan, a peripherally acting mu-opioid receptor (PAM-OR) antagonist for the treatment of opioid-induced bowel dysfunction: results from a randomized, double-blind, placebo- 
controlled, dose-finding study in subjects taking opioids for chronic non-cancer pain. Pain. 2008;137:428-40.

141. Paulson DM, Kennedy DT, Donovick RA, Carpenter RL, Cherubini M, Techner L, et al. Alvimopan: an oral, peripherally acting, mu-opioid receptor antagonist for the treatment of opioid-induced bowel dysfunction-a 21-day treatment-randomized clinical trial. J Pain. 2005;6:184-92.

142. Jansen JP, Lorch D, Langan J, Lasko B, Hermanns K, Kleoudis $\mathrm{CS}$, et al. A randomized, placebo-controlled phase 3 trial (Study SB-767905/012) of alvimopan for opioid-induced bowel dysfunction in patients with non-cancer pain. J Pain. 2011;12:185-93.

143. Irving G, Penzes J, Ramjattan B, Cousins M, Rauck R, Spierings EL, et al. A randomized, placebo-controlled phase 3 trial (Study SB-767905/013) of alvimopan for opioid-induced bowel dysfunction in patients with non-cancer pain. J Pain. 2011;12:175-84.

144. Wolff BG, Michelassi F, Gerkin TM, Techner L, Gabriel K, Du $\mathrm{W}$, et al. Alvimopan, a novel, peripherally acting mu opioid antagonist: results of a multicenter, randomized, double-blind, placebo-controlled, phase III trial of major abdominal surgery and postoperative ileus. Ann Surg. 2004;240:728-34.

145. Viscusi ER, Goldstein S, Witkowski T, Andonakakis A, Jan R, Gabriel K, et al. Alvimopan, a peripherally acting mu-opioid receptor antagonist, compared with placebo in postoperative ileus after major abdominal surgery: results of a randomized, double-blind, controlled study. Surg Endosc. 2006;20:64-70.

146. Buchler MW, Seiler CM, Monson JR, Flamant Y, ThompsonFawcett MW, Byrne MM, et al. Clinical trial: alvimopan for the management of post-operative ileus after abdominal surgery: results of an international randomized, double-blind, multicentre, placebo-controlled clinical study. Aliment Pharmacol Ther. 2008;28:312-25.

147. Taguchi A, Sharma N, Saleem RM, Sessler DI, Carpenter RL, Seyedsadr M, et al. Selective postoperative inhibition of gastrointestinal opioid receptors. N Engl J Med. 2001;345:935-40.

148. Ludwig K, Enker WE, Delaney CP, Wolff BG, Du W, Fort JG, et al. Gastrointestinal tract recovery in patients undergoing bowel resection: results of a randomized trial of alvimopan and placebo with a standardized accelerated postoperative care pathway. Arch Surg. 2008;143:1098-105.

149. Herzog TJ, Coleman RL, Guerrieri JP Jr, Gabriel K, Du W, Techner L, et al. A double-blind, randomized, placebo-controlled phase III study of the safety of alvimopan in patients who undergo simple total abdominal hysterectomy. Am J Obstet Gynecol. 2006;195:445-53.

150. Ludwig K, Viscusi ER, Wolff BG, Delaney CP, Senagore A, Techner L. Alvimopan for the management of postoperative ileus after bowel resection: characterization of clinical benefit by pooled responder analysis. World J Surg. 2010;34:2185-90.

151. Itawi EA, Savoie LM, Hanna AJ, Apostolides GY. Alvimopan addition to a standard perioperative recovery pathway. JSLS. 2011;15:492-8.

152. Poston S, Broder MS, Gibbons MM, Maclaren R, Chang E, Vandepol CJ, et al. Impact of alvimopan (entereg) on hospital costs after bowel resection: results from a large inpatient database. P T. 2011;36:209-20.

153. Delaney CP, Craver C, Gibbons MM, Rachfal AW, VandePol CJ, Cook SF, et al. Evaluation of clinical outcomes with alvimopan in clinical practice: a national matched-cohort study in patients undergoing bowel resection. Ann Surg. 2012;255:731-8.

154. Vaughan-Shaw PG, Fecher IC, Harris S, Knight JS. A metaanalysis of the effectiveness of the opioid receptor antagonist alvimopan in reducing hospital length of stay and time to GI recovery in patients enrolled in a standardized accelerated recovery program after abdominal surgery. Dis Colon Rectum. 2012;55:611-20.
155. Bader S, Jaroslawski K, Blum HE, Becker G. Opioid-induced constipation in advanced illness: safety and efficacy of methylnaltrexone bromide. Clin Med Insights Oncol. 2011;5:201-11.

156. Wong BS, Rao AS, Camilleri M, Manabe N, McKinzie S, Busciglio I, et al. The effects of methylnaltrexone alone and in combination with acutely administered codeine on gastrointestinal and colonic transit in health. Aliment Pharmacol Ther. 2010;32:884-93.

157. Murphy DB, Sutton JA, Prescott LF, Murphy MB. Opioidinduced delay in gastric emptying: a peripheral mechanism in humans. Anesthesiology. 1997;87:765-70.

158. Yuan CS, Foss JF, Osinski J, Toledano A, Roizen MF, Moss J. The safety and efficacy of oral methylnaltrexone in preventing morphine-induced delay in oral-cecal transit time. Clin Pharmacol Ther. 1997;61:467-75.

159. Michna E, Weil AJ, Duerden M, Schulman S, Wang W, Tzanis E, et al. Efficacy of subcutaneous methylnaltrexone in the treatment of opioid-induced constipation: a responder post hoc analysis. Pain Med. 2011;12:1223-30.

160. Iyer SS, Randazzo BP, Tzanis EL, Schulman SL, Zhang H, Wang W, et al. Effect of subcutaneous methylnaltrexone on patient-reported constipation symptoms. Value Health. 2011;14: 177-83.

161. Michna E, Blonsky ER, Schulman S, Tzanis E, Manley A, Zhang H, et al. Subcutaneous methylnaltrexone for treatment of opioid-induced constipation in patients with chronic, nonmalignant pain: a randomized controlled study. J Pain. 2011;12: 554-62.

162. Yu CS, Chun HK, Stambler N, Carpenito J, Schulman S, Tzanis E, et al. Safety and efficacy of methylnaltrexone in shortening the duration of postoperative ileus following segmental colectomy: results of two randomized, placebo-controlled phase 3 trials. Dis Colon Rectum. 2011;54:570-8.

163. Anissian L, Schwartz HW, Vincent K, Vincent HK, Carpenito J, Stambler N, et al. Subcutaneous methylnaltrexone for treatment of acute opioid-induced constipation: phase 2 study in rehabilitation after orthopedic surgery. J Hosp Med. 2012;7:67-72.

164. Chamberlain BH, Cross K, Winston JL, Thomas J, Wang W, Su $\mathrm{C}$, et al. Methylnaltrexone treatment of opioid-induced constipation in patients with advanced illness. J Pain Symptom Manage. 2009;38:683-90.

165. Slatkin N, Thomas J, Lipman AG, Wilson G, Boatwright ML, Wellman C, et al. Methylnaltrexone for treatment of opioidinduced constipation in advanced illness patients. J Support Oncol. 2009;7:39-46.

166. Portenoy RK, Thomas J, Moehl Boatwright ML, Tran D, Galasso FL, Stambler N, et al. Subcutaneous methylnaltrexone for the treatment of opioid-induced constipation in patients with advanced illness: a double-blind, randomized, parallel group, dose-ranging study. J Pain Symptom Manage. 2008;35:458-68.

167. Lipman AG, Karver S, Cooney GA, Stambler N, Israel RJ. Methylnaltrexone for opioid-induced constipation in patients with advanced illness: a 3-month open-label treatment extension study. J Pain Palliat Care Pharmacother. 2011;25:136-45.

168. Yuan CS, Foss JF, O'connor M, Osinski J, Karrison T, Moss J, et al. Methylnaltrexone for reversal of constipation due to chronic methadone use: a randomized controlled trial. JAMA. 2000;283:367-72.

169. Garnock-Jones KP, McKeage K. Methylnaltrexone. Drugs. 2010;70:919-28.

170. Garten L, Degenhardt P, Buhrer C. Resolution of opioid-induced postoperative ileus in a newborn infant after methylnaltrexone. J Pediatr Surg. 2011;46:e13-5.

171. Fichna J, Gach K, Perlikowska R, Cravezic A, Bonnet JJ, do-Rego JC, et al. Novel endomorphin analogues with 
antagonist activity at the mu-opioid receptor in the gastrointestinal tract. Regul Pept. 2010;162:109-14.

172. Fichna J, Storr MA. Brain-gut interactions in IBS. Front Pharmacol. 2012;3:127.

173. Farup PG, Sperber AD, Simren M. Irritable bowel syndrome. Gastroenterol Res Pract. 2012;2012:612479.

174. Andrews EB, Eaton SC, Hollis KA, Hopkins JS, Ameen V, Hamm LR, et al. Prevalence and demographics of irritable bowel syndrome: results from a large web-based survey. Aliment Pharmacol Ther. 2005;22:935-42.

175. Wilkins T, Pepitone C, Alex B, Schade RR. Diagnosis and management of IBS in adults. Am Fam Physician. 2012;86:419-26.

176. Philpott H, Gibson P, Thien F. Irritable bowel syndrome-an inflammatory disease involving mast cells. Asia Pac Allergy. 2011;1:36-42.

177. Alaradi O, Barkin JS. Irritable bowel syndrome: update on pathogenesis and management. Med Princ Pract. 2002;11:2-17.

178. Distrutti E, Mencarelli A, Renga B, Caliendo G, Santagada V, Severino B, et al. A nitro-arginine derivative of trimebutine (NO2-Arg-Trim) attenuates pain induced by colorectal distension in conscious rats. Pharmacol Res. 2009;59:319-29.

179. Lee N, Wald A. Linaclotide: evidence for its potential use in irritable bowel syndrome and chronic constipation. Core Evid. 2012;7:39-47.

180. Olden KW. Targeted therapies for diarrhea-predominant irritable bowel syndrome. Clin Exp Gastroenterol. 2012;5:69-100.

181. Gross KJ, Pothoulakis C. Role of neuropeptides in inflammatory bowel disease. Inflamm Bowel Dis. 2007;13:918-32.

182. Philippe D, Dubuquoy L, Groux H, Brun V, Chuoi-Mariot MT, Gaveriaux-Ruff C, et al. Anti-inflammatory properties of the mu opioid receptor support its use in the treatment of colon inflammation. J Clin Invest. 2003;111:1329-38.

183. Srinath AI, Walter C, Newara MC, Szigethy EM. Pain management in patients with inflammatory bowel disease: insights for the clinician. Therap Adv Gastroenterol. 2012;5:339-57.

184. Cabot PJ, Carter L, Gaiddon C, Zhang Q, Schafer M, Loeffler JP, et al. Immune cell-derived beta-endorphin. Production, release, and control of inflammatory pain in rats. J Clin Invest. 1997;100:142-8.

185. Tomassini N, Renaud FL, Roy S, Loh HH. Mu and delta receptors mediate morphine effects on phagocytosis by murine peritoneal macrophages. J Neuroimmunol. 2003;136:9-16.
186. Philippe D, Chakass D, Thuru X, Zerbib P, Tsicopoulos A, Geboes $\mathrm{K}$, et al. $\mathrm{Mu}$ opioid receptor expression is increased in inflammatory bowel diseases: implications for homeostatic intestinal inflammation. Gut. 2006;55:815-23.

187. Goldsmith JR, Uronis JM, Jobin C. Mu opioid signaling protects against acute murine intestinal injury in a manner involving Stat3 signaling. Am J Pathol. 2011;179:673-83.

188. Matters GL, Harms JF, McGovern C, Fitzpatrick L, Parikh A, Nilo N, et al. The opioid antagonist naltrexone improves murine inflammatory bowel disease. J Immunotoxicol. 2008;5:179-87.

189. Jan WC, Chen CH, Hsu K, Tsai PS, Huang CJ. L-type calcium channels and mu-opioid receptors are involved in mediating the anti-inflammatory effects of naloxone. J Surg Res. 2011;167:e 263-72.

190. Smith JP, Bingaman SI, Ruggiero F, Mauger DT, Mukherjee A, McGovern CO, et al. Therapy with the opioid antagonist naltrexone promotes mucosal healing in active Crohn's disease: a randomized placebo-controlled trial. Dig Dis Sci. 2011;56:2088-97.

191. Hilburger ME, Adler MW, Truant AL, Meissler JJ Jr, Satishchandran V, Rogers TJ, et al. Morphine induces sepsis in mice. J Infect Dis. 1997;176:183-8.

192. Topcu I, Ekici NZ, Isik R, Sakarya M. The effects of tramadol and fentanyl on gastrointestinal motility in septic rats. Anesth Analg. 2006;102:876-81.

193. Nardi GM, Bet AC, Sordi R, Fernandes D, Assreuy J. Opioid analgesics in experimental sepsis: effects on physiological, biochemical, and haemodynamic parameters. Fundam Clin Pharmacol. 2012;. doi:10.1111/j.1472-8206.2012.01041.x.

194. Tang CW, Feng WM, Du HM, Bao Y, Zhu M. Delayed administration of D-Ala2-D-Leu5-enkephalin, a delta-opioid receptor agonist, improves survival in a rat model of sepsis. Tohoku J Exp Med. 2011;224:69-76.

195. Goins WF, Cohen JB, Glorioso JC. Gene therapy for the treatment of chronic peripheral nervous system pain. Neurobiol Dis. 2012;48:255-70.

196. Fink DJ, Wechuck J, Mata M, Glorioso JC, Goss J, Krisky D, et al. Gene therapy for pain: results of a phase I clinical trial. Ann Neurol. 2011;70:207-12. 